OPEN ACCESS

Edited by:

Diana Dudziak,

Universitätsklinikum Erlangen,

Germany

Reviewed by

Alexander Mildner, Helmholtz-Gemeinschaft Deutscher Forschungszentren (HZ), Germany Luigi Racioppi,

Università degli Studi di Napoli

Federico II, Italy

*Correspondence:

Stella E. Autenrieth

stella.autenrieth@

med.uni-tuebingen.de

Specialty section:

This article was submitted to Antigen Presenting Cell Biology,

a section of the journal

Frontiers in Immunology

Received: 27 July 2018

Accepted: 23 October 2018

Published: 13 November 2018

Citation:

Richardson JR, Armbruster NS, Günter M, Henes J and Autenrieth SE (2018) Staphylococcus aureus PSM

Peptides Modulate Human Monocyte-Derived Dendritic Cells to Prime Regulatory T Cells. Front. Immunol. 9:2603. doi: 10.3389/fimmu.2018.02603

\section{Staphylococcus aureus PSM Peptides Modulate Human Monocyte-Derived Dendritic Cells to Prime Regulatory T Cells}

\author{
Jennifer R. Richardson, Nicole S. Armbruster, Manina Günter, Jörg Henes and \\ Stella E. Autenrieth*
}

Department of Internal Medicine II, University of Tübingen, Tübingen, Germany

Staphylococcus aureus (Sa), as one of the major human pathogens, has very effective strategies to subvert the human immune system. Virulence of the emerging community-associated methicillin-resistant Sa (CA-MRSA) depends on the secretion of phenol-soluble modulin (PSM) peptide toxins e.g., by binding to and modulation of innate immune cells. Previously, by using mouse bone marrow-derived dendritic cells we demonstrated that PSMs in combination with various Toll-like receptor (TLR) ligands induce a tolerogenic DC phenotype (tDC) characterized by the production of IL-10 and impaired secretion of pro-inflammatory cytokines. Consequently, PSM-induced tDCs favored priming of $\mathrm{CD} 4^{+} \mathrm{CD} 25^{+} \mathrm{FoxP}^{+} \mathrm{T}_{\text {regs }}$ with suppressor function while impairing the Th1 response. However, the relevance of these findings for the human system remained elusive. Here, we analyzed the impact of PSM $\alpha 3$ on the maturation, cytokine production, antigen uptake, and T cell stimulatory capacity of human monocyte-derived DCs (moDCs) treated simultaneously with either LPS (TLR4 ligand) or Sa cell lysate (TLR2 ligand). Herein, we demonstrate that PSMs indeed modulate human moDCs upon treatment with TLR2/4 ligands via multiple mechanisms, such as transient pore formation, impaired DC maturation, inhibited pro- and anti-inflammatory cytokine secretion, as well as reduced antigen uptake. As a result, the adaptive immune response was altered shown by an increased differentiation of naïve and even CD4 ${ }^{+} \mathrm{T}$ cells from patients with Th1/Th17-induced diseases (spondyloarthritis and rheumatoid arthritis) into $\mathrm{CD} 4^{+} \mathrm{CD} 127^{-} \mathrm{CD} 25^{\text {hi }} \mathrm{CD} 45 \mathrm{RA}{ }^{-}$FoxP3 ${ }^{\text {hi }}$ regulatory $\mathrm{T}$ cells $\left(\mathrm{T}_{\text {regs }}\right)$ with suppressor function. This $T_{\text {reg }}$ induction was mediated most predominantly by direct DC-T-cell interaction. Thus, PSMs from highly virulent Sa strains affect DC functions not only in the mouse, but also in the human system, thereby modulating the adaptive immune response and probably increasing the tolerance toward the bacteria. Moreover, PSM $\alpha 3$ might be a novel peptide for tolerogenic DC induction that may be used for DC vaccination strategies.

Keywords: monocyte-derived dendritic cells, Staphylococcus aureus, phenol-soluble modulins, immune tolerance, immunity, regulatory $\mathrm{T}$ cells 


\section{INTRODUCTION}

Dendritic cells (DCs) are specialized antigen presenting cells (APCs) able to prime naïve $\mathrm{T}$ cells thereby inducing a primary immune response and maintaining self-tolerance (1). Initially DCs occur in an immature state, specialized for antigen uptake with a high endocytic capability (2). The recognition of pathogens via germ-line encoded pattern-recognition receptors, like Toll-like Receptors (TLRs), leads to DC maturation (3). This event is characterized by the loss of their endocytic capacities and the upregulation of CCR7, co-stimulatory molecules, and HLA$\mathrm{DR}$, necessary for homing into the draining lymph node and T-cell priming (4). Furthermore, DCs secrete pro-inflammatory cytokines, such as TNF- $\alpha$, IL- 6 or IL-12, which recruit other immune cells for pathogen clearance and contribute to $\mathrm{T}$ helper cell (Th) differentiation (5). Apart from inducing an efficient immune response, DCs are also crucial for maintaining immune tolerance in the steady-state. Although the specific phenotype of so-called tolerogenic DCs (tDCs) and the molecular mechanism involved in tolerance induction by these cells are not entirely defined (6-9) they are characterized by an immature phenotype and produce high amounts of anti-inflammatory cytokines, e.g., IL-10 and TGF- $\beta$, which possess critical immunoregulatory functions like controlling/regulating the production of proinflammatory cytokines. They have the potential to induce regulatory $\mathrm{T}$ cell $\left(\mathrm{T}_{\text {reg }}\right)$ expansion thereby impairing effector $\mathrm{T}$ cell responses $(8,10-12)$.

Various pathogens and tumors can induce tDCs and subsequent $\mathrm{T}_{\text {reg }}$ differentiation as immune escape strategy to impair clearance. This process is mediated by pathogenic products from e.g., C. albicans, S. mansoni and V. cholerae, which are partially used for the production of immunosuppressive drugs. These are widely used for therapy of autoimmune diseases or transplant rejections even though they have severe side effects by suppressing the entire host immune system $(11,13)$. Therefore, DC vaccination strategies by applying tDCs are an attractive alternative $(8,9,13)$. Several clinical trials started to analyze the effect of $\mathrm{tDCs}$ as treatment option for patients with autoimmune disorders (8).

Phenol-soluble modulins (PSMs) are short amphipathic $\alpha$-helical peptides, which are produced by highly virulent Staphylococci, such as community-associated Methicillinresistant Staphylococcus aureus (Sa) promoting, e.g., cell lysis thereby evading clearance by immune cells $(14,15)$. Two types of PSMs are distinguished according to their length: $\alpha$-type PSMs ( 20-25 AA) and $\beta$-type PSMs ( 44 AA) (16). The PSM $\alpha$ peptides are the most potent PSMs regarding cytolysis and highly contribute to the virulence of Sa $(16,17)$. Own previous studies with mouse bone-marrow derived DCs (BM-DCs) showed that

Abbreviations: APC, antigen presenting cell; BM-DCs, bone-marrow derived DCs; CA-MRSA, community-associated methicillin-resistant Sa; DCs, dendritic cells; IDO, indolamin-2,3-dioxygenase; $\mathrm{iT}_{\text {regs }}$, induced regulatory T cells; $\mathrm{LDH}, \mathrm{L}$ lactate dehydrogenase; moDCs, monocyte-derived DCs; PBMCs, peripheral blood mononuclear cells; PSM, phenol-soluble modulin peptides; Sa, Staphylococcus aureus; Sa lysate, Staphylococcus aureus cell lysate; tDCs, tolerogenic DCs; Th, $\mathrm{T}$ helper cell; TLR, Toll-like receptor; TLRL, Toll-like receptor ligand; $\mathrm{T}_{\text {regs }}$, regulatory $\mathrm{T}$ cells.
PSM $\alpha 3$ prime tDCs when co-incubated with various TLR ligands (TLRL), regardless which TLR was activated. Molecularly, this event is characterized by the increased activation of the p38-CREB pathway, which in consequence leads to diminished pro-inflammatory cytokine production but increased IL10 secretion. These PSM-induced tDCs favored priming of $\mathrm{CD}^{+} \mathrm{CD} 25^{+} \mathrm{FoxP}^{+} \mathrm{T}_{\text {regs }}$ with suppressor function $(10,12,18)$. Thus, we hypothesized that PSMs of Sa likewise induce tDCs in the human system.

Herein, we show that PSM $\alpha 3$ penetrates and modulates human monocyte-derived DCs (moDCs) by altering the TLR2- or TLR4-induced maturation, inhibiting pro- and antiinflammatory cytokine production and reducing antigen uptake, but producing indolamin-2,3-dioxygenase (IDO). As a result, the frequency of $\mathrm{CD} 4{ }^{+} \mathrm{CD} 127^{-} \mathrm{CD} 25^{\text {hi }} \mathrm{CD} 45 \mathrm{RA}{ }^{-}$Foxp $3{ }^{\text {hi }} \mathrm{T}_{\text {regs }}$ is increased, while Th1 responses are diminished. Moreover, PSM $\alpha 3$-induced tDCs from healthy donors even enhanced differentiation of $\mathrm{CD}^{+} \mathrm{T}$ cells from patients with Th17associated autoimmune diseases to $\mathrm{T}_{\text {regs }}$. Thus, PSM $\alpha 3$ might be a novel peptide for manipulating DCs to become tolerogenic for DC vaccination strategies.

\section{MATERIALS AND METHODS}

\section{Research Subjects}

Buffy coats from healthy volunteers were obtained from the ZKT Tübingen GmbH. Fresh blood was obtained from healthy volunteers with informed consent. This was approved by the ethical review committee of the medical faculty of the Eberhard-Karls-University of Tübingen with the project number $633 / 2012 \mathrm{BO}$. Blood from patients with TH17-associated autoimmune diseases were obtained from the division of Rheumatology, Department of Internal Medicine II, University Hospital Tübingen. This was approved by the ethical review committee of the medical faculty of the Eberhard-KarlsUniversity of Tübingen with the project number 046/2015BO2.

\section{Reagents}

Formylated PSM peptides (PSM $\alpha 3, \delta$-Toxin) were synthesized at the Interfaculty Institute of Cell Biology, Department of Immunology, University of Tübingen. FITC-labeled PSM $\alpha 2$ was synthesized at the Group of Hubert Kalbacher, Interfaculty Institute of Biochemistry, University of Tübingen. Sa cell lysate (Sa lysate) containing lipopeptides and specifically activating TLR2 was prepared from a protein A-deficient Sa mutant strain (SA113) and provided by Andreas Peschel, Interfaculty Institute of Microbiology and Infection Medicine, University of Tübingen.

\section{Isolation of Peripheral Blood Mononuclear Cells}

Buffy coats or fresh blood was diluted with Dulbecco's PBS (Life Technologies) (Buffy Coats 1:7 blood: PBS; Fresh blood 1:1 blood: PBS). Peripheral blood mononuclear cells (PBMCs) were obtained by density gradient centrifugation at $2000 \mathrm{rpm}$ for $20 \mathrm{~min}$ at room temperature with $35 \mathrm{~mL}$ cell suspension stacked on $15 \mathrm{~mL}$ Biocoll separation solution (Biochrom). The interphase containing the PBMCs was abstracted and washed twice with 
PBS. PBMCs were further used to generate human moDCs and for the isolation of naïve $\mathrm{CD} 4^{+} \mathrm{T}$ cells and $\mathrm{CD} 4^{+} \mathrm{T}$ cells.

\section{Generation of Human Monocyte-Derived DCs}

PBMCs were plated in a tissue-treated 6-well plate $\left(6 \times 10^{6}\right.$ cells per well) in DC medium [RPMI1640 (Merck), 10\% FBS (Sigma), $2 \mathrm{mM}$ L-Glutamine (Life Technologies), $100 \mathrm{U} / \mathrm{mL}$ PenicillinStreptomycin (Life Technologies), $1 \times$ non-essential amino acids (Merck), $1 \mathrm{mM}$ sodium pyruvate (Merck) and $50 \mu \mathrm{M} 2$ mercaptoethanol (Roth)] and incubated for $1 \mathrm{~h}$ at $37^{\circ} \mathrm{C}, 5 \% \mathrm{CO}_{2}$. After that, wells were washed with medium and PBS discarding the non-adherent cells. $3 \mathrm{~mL} /$ well DC medium containing $50 \mathrm{ng}$ IL-4 and 100 ng GM-CSF (both from Miltenyi) was added to the remaining cells. Cells were incubated for $6 \mathrm{~d}$ at $37^{\circ} \mathrm{C}, 5 \% \mathrm{CO}_{2}$. Cytokines were again added on day 2 and day 4 . At day 6 the cells were used for the following experiments. The purity of the moDC culture was always $>90 \%$ of leukocytes (Figure S1).

\section{Cytokine/Indolamin-2,3-Dioxygenase Production by moDCs}

MoDCs $\left(2.5 \times 10^{5}\right)$ were seeded in a 96-well plate and treated with $3 \mu \mathrm{g} / \mathrm{mL}$ Sa lysate or $100 \mathrm{ng} / \mathrm{mL}$ LPS in combination with or without PSM $\alpha 3(10 \mu \mathrm{M})$. For some experiments moDCs were treated with different concentrations of PSM $\alpha 3$ or additionally stimulated with $100 \mathrm{ng} / \mathrm{mL}$ Pam2CSK4 (for TLR2/TLR6; InvivoGen), $1 \mu \mathrm{g} / \mathrm{mL}$ Pam3CSK4 (for TLR1/TLR2; InvivoGen), $1 \mu \mathrm{g} / \mathrm{mL}$ CpG ODN 2395 (for TLR9; InvivoGen), $5 \mu \mathrm{g} / \mathrm{mL}$ Imiquimod (for TLR7; InvivoGen), $2 \mu \mathrm{g} / \mathrm{mL}$ Flagellin (for TLR5; InvivoGen) or $10 \mu \mathrm{g} / \mathrm{mL}$ LTA (for TLR2/TLR4; InvivoGen) in combination with or without PSM $\alpha 3(10 \mu \mathrm{M})$. Supernatants were collected after $6 \mathrm{~h}, 24 \mathrm{~h}$ or $48 \mathrm{~h}$ and analyzed for TNF, IL-10, IL-12 and IDO production, respectively. Cytokines and IDO in the supernatants were determined by sandwich ELISA [eBioscience (TNF, IL-10, IL-12), R\&D Systems (IDO)] according to the manufacturer's instructions.

\section{Flow Cytometry}

For moDC surface marker analysis of the costimulatory and inhibitory molecules, moDCs $\left(2 \times 10^{5}\right)$ were seeded in a 96-well plate and stimulated with $3 \mu \mathrm{g} / \mathrm{mL}$ Sa lysate or $100 \mathrm{ng} / \mathrm{mL}$ LPS with or without PSM $\alpha 3(10 \mu \mathrm{M})$ or PSM $\alpha 3$ alone for $6 \mathrm{~h}$ or $24 \mathrm{~h}$. Cells were removed from the plate using Accutase (Sigma-Aldrich) and treated with IgG from human serum (1 $\mathrm{g}$ g of human IgG per 100,000 cells; SigmaAldrich) for $20 \mathrm{~min}$ at room temperature to avoid unspecific binding via Fc receptors. Cells were stained with ZombieAqua (BioLegend) to exclude dead cells and fluorochrome conjugated extracellular antibodies: HLA-DR BV650 (L243, BioLegend), CD11b BV510 (ICRF44, BioLegend), CD11c APC (MJ4-27G121, Miltenyi), CD11c PE-Cy7 (Bu15, BioLegend), CD40 FITC (5C3, eBioscience), CD80 PE-Cy7 (2D10, BioLegend), CD83 PE-Dazzle 594 (HB15e, BioLegend), CD86 BV605 (IT2.2, BioLegend), PD-L1 PE (29E.2A3, BioLegend), PD-L2 PE (MIH18), ILT3 PE (ZM4.1, BioLegend) for $20 \mathrm{~min}$ at $4^{\circ} \mathrm{C}$. FACS buffer [PBS containing 1\% FBS, $2 \mathrm{mM}$ EDTA (Merck) and 0.09\% $\mathrm{NaN}_{3}$ (Sigma-Aldrich)] was used for all incubations and washing steps. At least 50,000 cells were acquired using a LSR Fortessa flow cytometer (BD Biosciences) with the DIVA software (BD Biosciences) and were further analyzed using FlowJo 10.4.2 software (Tree Star).

\section{Phosphoflow}

For the experiments analyzing phosphorylation of signaling cascades, moDCs $\left(2 \times 10^{5}\right)$ were seeded in a 96-well plate and treated for $1 \mathrm{~h}$ with $100 \mathrm{ng} / \mathrm{mL}$ LPS with or without PSM $\alpha 3$ $(10 \mu \mathrm{M})$ or PSM $\alpha 3$ alone. Cells were removed from the plate using Accutase and treated with IgG from human serum (1 $\mu \mathrm{g}$ of human IgG per 100,000 cells) for $20 \mathrm{~min}$ at room temperature to avoid unspecific binding via Fc receptors. Cells were stained with ZombieAqua (BioLegend) to exclude dead cells and fluorochrome conjugated extracellular antibodies: HLADR PE (L243; BD Biosciences) and CD11c APC/Cy7 (Bu15; BioLegend) for $20 \mathrm{~min}$ at $4{ }^{\circ} \mathrm{C}$. To detect intracellular p-p38 and $\mathrm{p}-\mathrm{NF}-\kappa \mathrm{B}$ cells were fixed with $2 \%$ paraformaldehyde (VWR) in PBS, permeabilized with 90\% freezing methanol (Applichem) overnight and stained with the primary Abs to phospho-p38 MAPK (Thr180/Tyr182; clone 12F8) or phospho-NF- $\mathrm{B}$ p65 (Ser536; clone: 93H1) (both from Cell Signaling) for $1 \mathrm{~h}$ in the dark at room temperature followed by DyLight649-conjugated AffiniPure Goat At-Rabbit IgG (Jackson ImmunoResearch) for $15 \mathrm{~min}$ at $4^{\circ} \mathrm{C}$. PBS with $0.5 \% \mathrm{BSA}$ (Biomol) was used for incubation and washing steps of intracellular antibody stainings. At least 50,000 cells were acquired using a Canto-II (BD Biosciences) with DIVA software (BD Biosciences) and were further analyzed using the FlowJo 10.4.2 software (Tree Star).

\section{Measurement of Antigen Uptake by Flow Cytometry or Multispectral Imaging Flow Cytometry}

MoDCs $\left(5 \times 10^{5}\right)$ were seeded in a 48 -well plate and stimulated for $24 \mathrm{~h}$ with $3 \mu \mathrm{g} / \mathrm{mL}$ Sa lysate or $100 \mathrm{ng} / \mathrm{mL}$ LPS with or without PSM $\alpha 3(10 \mu \mathrm{M})$ or PSM $\alpha 3$ alone prior to the incubation with Ovalbumin (OVA)-AlexaFluor647 $(5 \mu \mathrm{g} / \mathrm{mL}$, Invitrogen) together with PSM $\alpha 2$ FITC $(0.5 \mu \mathrm{M})$ for $30 \mathrm{~min}$ at $37^{\circ} \mathrm{C}$, $5 \% \mathrm{CO}_{2}$. Unspecific binding of OVA/PSM $\alpha 2$ was assessed by incubating the cells on ice. Cells were washed twice with ice-cold PBS containing 2\% FBS. Subsequently, cells were blocked and stained with ZombieAqua (BioLegend), HLA-DR BV650 (L243, BioLegend), HLA-DR APC-Cy7 (L243, BioLegend) and CD11c PE-Cy7 (Bu15, BioLegend) as described above and analyzed by flow cytometry or by multispectral imaging flow cytometry. For the latter, images of 10,000 living moDCs were acquired using the Image-Stream mkII (Amnis) with the INSPIRE instrument controller software. The data were analyzed using the IDEAS analysis software (Merck Millipore).

\section{Lactate Dehydrogenase Release}

MoDCs $\left(2 \times 10^{5}\right)$ were seeded in a 96-well plate and treated with Triton X100 (1\%; Sigma-Aldrich), DMSO (2\%, Fluka), PSM $\alpha 2$ $(10 \mu \mathrm{M}), \operatorname{PSM} \alpha 3(2.5,5,7.5$, and $10 \mu \mathrm{M}), \delta$-Toxin $(10 \mu \mathrm{M})$ or OVA (10 $\mu \mathrm{g}$, Sigma-Aldrich) for $10 \mathrm{~min}$ at $37^{\circ} \mathrm{C}, 5 \% \mathrm{CO}_{2}$. Cell death was determined using 7-aminoactinomycin D (7-AAD, Biomol) staining and acquisition on a Canto II flow cytometer. 


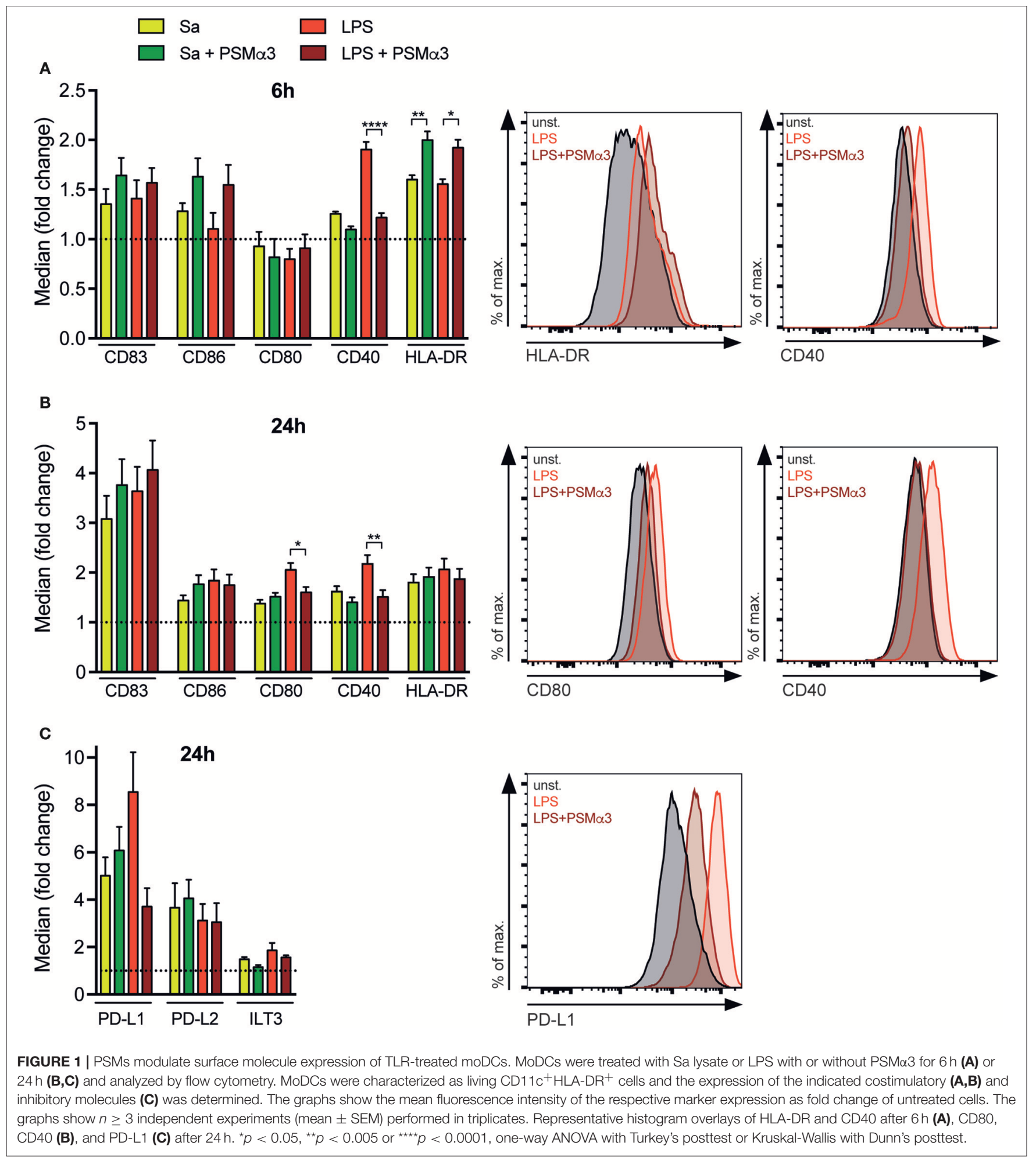

Supernatants were used for the analysis of lactate dehydrogenase (LDH) release using the Cytotoxicity Detection Kit (Roche) according to the manufacturer's instructions. Absorbance was measured at $492 \mathrm{~nm}$ and $620 \mathrm{~nm}$ over a period of $1 \mathrm{~h}$ with an interval of 5 min using the Spark $10 \mathrm{M}$ microplate reader (Tecan).

\section{T-Cell Assay}

MoDCs $\left(5 \times 10^{4}\right)$ were seeded in a 96-well plate and stimulated with $3 \mu \mathrm{g} / \mathrm{mL}$ Sa lysate or $100 \mathrm{ng} / \mathrm{mL}$ LPS with or without PSM $\alpha 3$ $(10 \mu \mathrm{M})$ or PSM $\alpha 3$ alone for $24 \mathrm{~h}$. For some experiments moDCs were pre-treated with $200 \mu \mathrm{M}$ 1-Methyl-D-tryptophan (1-DMT) 
for $1 \mathrm{~h}$ prior to the stimulation. Human naïve $\mathrm{CD} 4^{+} \mathrm{T}$ cells were isolated from PBMCs using the MojoSort ${ }^{\mathrm{TM}}$ Human CD4 Naïve $\mathrm{T}$ Cell Isolation Kit (BioLegend) according to the manufacturer's instructions. For the magnetic cell separation, a LS column (Miltenyi Biotech) was placed into the QuadroMACS Separator (Miltenyi Biotech) and rinsed with MACS buffer (PBS containing $0,5 \%$ BSA (Biomol) and $2 \mathrm{mM}$ EDTA). The cell suspension was applied to the column, and the column was washed three times with $3 \mathrm{~mL}$ MACS buffer. The untouched naïve $\mathrm{CD} 4^{+} \mathrm{T}$ cells were collected in the flow through. The purity of isolated (naïve) $\mathrm{CD}^{+} \mathrm{T}$ cells was always $\approx 85 \%$ (Figure $\mathrm{S} 4$ ). The naïve $\mathrm{CD}^{+} \mathrm{T}$ cells were labeled with CFSE $(5 \mu \mathrm{M}$, BioLegend) according to the manufacturer's instructions. $2 \times 10^{5} \mathrm{~T}$ cells diluted in $100 \mu \mathrm{L}$ T cell medium [RPMI1640 (Merck), 10\% FBS (Sigma), 2 mM L-Glutamine (Life Technologies), $100 \mathrm{U} / \mathrm{mL}$ penicillin-streptomycin (Life Technologies), $1 \times$ non-essential amino acids (Merck), $1 \mathrm{mM}$ sodium pyruvate (Merck), $10 \mathrm{mM}$ HEPES (Biochrom) and $50 \mu \mathrm{M} 2$-mercaptoethanol (Roth)] were added to the moDCs. To investigate whether secreted factors from DCs upon PSM-treatment mediate $\mathrm{T}_{\text {reg }}$ priming, $\mathrm{T}$ cells were co-cultured with untreated moDCs adding conditioned medium from LPS or LPS + PSM $\alpha 3$ stimulated DCs. In a second assay moDCs treated as described above were splitted using Accutase (Sigma-Aldrich) for $5 \mathrm{~min}$ at room temperature and again sowed with either fresh or conditioned DC medium (TLRL or TLRL + PSM $\alpha 3$ ). In some conditions, DC were fixed with $1 \%$ paraformaldehyde for $10 \mathrm{~min}$ at $4^{\circ} \mathrm{C}$ to address the impact of newly secreted factors on $\mathrm{T}_{\text {reg }}$ priming by DCs. 3-4 d after co-culture $\mathrm{T}$ cells were blocked with IgG from human serum for $15 \mathrm{~min}$ at room temperature and subsequently stained with ZombieAqua, CD4 APC-Vio770 (REA623, Miltenyi), CD3 Pacific Blue (SK7, BioLegend), CD25 PE-Cy7 (BC96, eBiosciences), CD127 PE (eBioRDR5, eBiosciences) and CD45RA BV605 (HI100, BioLegend) for $20 \mathrm{~min}$ at $4^{\circ} \mathrm{C}$. For intracellular staining, cells were fixed and permeabilized with the Foxp3/ Transcription Factor Staining Buffer Set (eBiosciences), blocked and stained with CD4 APC-Vio770, CD3 Pacific Blue, FoxP3 AlexaFluor647 (259D, BioLegend), T-bet PE-Dazzle 594 (4B10, BioLegend), GATA3 PerCP-Cy5.5 (16E10A23, BioLegend) and ROR $\gamma$ t BV650 (Q21559 , BD Biosciences) for $45 \mathrm{~min}$ at $4^{\circ} \mathrm{C}$. FACS buffer was used for all incubations and washing steps for the extracellular staining, and $1 \times$ permeabilization buffer (Foxp3/Transcription Factor Staining Buffer Set (eBiosciences) was used for all incubations and washing steps for the intracellular staining. At least 70,000 cells were acquired using an LSR Fortessa flow cytometer (BD Biosciences) with the DIVA software (BD Biosciences) and were further analyzed using FlowJo 10.4.2 software (Tree Star).

\section{Autologous T-Cell Assay}

$\mathrm{CD}_{14}{ }^{+}$cells from PBMCs of patients with TH17-associated autoimmune diseases were isolated by MACS using CD14 MicroBeads (Miltenyi Biotech) and plated in a tissue-treated 6well plate $\left(1.3 \times 10^{6}\right.$ cells per well $)$ in DC medium containing $50 \mathrm{ng}$ IL-4 and $100 \mathrm{ng}$ GM-CSF for $6 \mathrm{~d}$ to generate moDCs. The remaining $\mathrm{CD} 14^{-}$cells were frozen at $-80^{\circ} \mathrm{C}$ in RPMI 1640 supplemented with $20 \% \mathrm{FBS}$ and 10\% DMSO. After $6 \mathrm{~d}$ moDCs $\left(5 \times 10^{4}\right)$ were seeded in a 96-well plate and stimulated with $100 \mathrm{ng} / \mathrm{mL}$ LPS with or without PSM $\alpha 3(10 \mu \mathrm{M})$ for $24 \mathrm{~h}$. The $\mathrm{CD}^{-} 4^{-}$cells were thawed and used to isolate $\mathrm{CD} 4^{+} \mathrm{T}$ cells by MACS with CD4 MicroBeads (Miltenyi Biotech). The CD4 ${ }^{+} \mathrm{T}$ cells were labeled with CFSE ( $5 \mu \mathrm{M}$, BioLegend) according to the manufacturer's instructions and $2 \times 10^{5} \mathrm{~T}$ cells diluted in 100 $\mu \mathrm{L}$ T cell medium were added to the moDCs. 3-4 days after coculture $\mathrm{T}$ cells were stained as above and $\mathrm{iT}_{\text {regs }}$ were analyzed by flow cytometry using an LSR Fortessa flow cytometer (BD Biosciences) with the DIVA software (BD Biosciences) and were further analyzed using FlowJo 10.4.2 software (Tree Star).

\section{Cytokine Production in the moDC T Cell Co-culture}

Fifty microliter cell culture supernatants from the $\mathrm{T}$ cell assay were taken on day 1, 2 and 3 and cytokine production from 15 $\mu \mathrm{L}$ was analyzed by performing bead-based immunoassays in a 96-well plate [LEGENDplex human B cell Panel (13-Plex) and LEGENDplex Free Active/Total TGF- $\beta 1$ (BioLegend)] according to the manufacturer's instructions, using the Lyric flow cytometer with autosampler (BD Bioscience).

\section{T Cell Suppression Assay}

MoDCs $\left(2 \times 10^{5}\right)$ were seeded in a 48 -well plate and stimulated with $100 \mathrm{ng} / \mathrm{mL}$ LPS and $10 \mu \mathrm{M}$ PSM $\alpha 3$ for $24 \mathrm{~h}$. Human $\mathrm{CD}^{+}{ }^{+} \mathrm{T}$ cells were isolated from PBMCs using the human CD4 MicroBeads Kit (Miltenyi) according to the manufacturer's instructions using LS columns. $8 \times 10^{5} \mathrm{~T}$ cells were added to the stimulated moDCs and cultured for $4 \mathrm{~d}$ at $37^{\circ} \mathrm{C}, 5 \%$ $\mathrm{CO}_{2}$. T cells were stained with CD4 APC-Vio770, CD25 PECy7, CD127 PE and CD45RA PerCP (HI100, BioLegend) as described above and dead cells were excluded using DAPI (Sigma-Aldrich,16,7 ng/mL). $\mathrm{T}_{\text {regs }}$ were purified by FACS sorting using an ARIA IIu cell sorter (BD Bioscience), according to the surface molecule expression $\left(\mathrm{CD} 4{ }^{+} \mathrm{CD} 127^{-} \mathrm{CD} 25^{\mathrm{hi}} \mathrm{CD} 45 \mathrm{RA}^{-}\right.$, see Figure S7). $\mathrm{CD}^{+} \mathrm{T}$ cells isolated from PBMCs from a different donor were used as $\mathrm{T}$ effector $\left(\mathrm{T}_{\mathrm{eff}}\right)$ cells purified with CD4 MicroBeads Kit (Miltenyi). The $\mathrm{T}_{\text {effs }}$ were labeled with CFSE $(5 \mu \mathrm{M})$, and $8 \times 10^{4}$ cells were seeded in a 96- well plate in $\mathrm{T}$ cell medium together with the indicated numbers of sorted $\mathrm{T}_{\text {regs }}$. For $\mathrm{T}$ cell activation of the $\mathrm{T}_{\mathrm{effs}}$ Dynabeads (Human $\mathrm{T}$ Activator CD3/CD28Proliferation; Gibco) were added according to the manufacturer's instructions. The proliferation of $\mathrm{T}_{\text {effs }}$ was assessed after $3 \mathrm{~d}$ by flow cytometry. Dead cells were excluded by staining the cells with ZombieAqua. 20,000 cells were acquired at the Canto II with the DIVA software (BD Biosciences) and were further analyzed using the proliferation tool in FlowJo 10.4.2 software (Tree Star).

\section{Statistical Analysis}

Statistical analysis was performed using GraphPad Prism 7.0a software (GraphPad, San Diego, CA). Statistical differences were determined using one-way ANOVA with Turkey's posttest in case data were normally distributed (Shapiro-Wilk normality test). Otherwise, data were analyzed using the KruskalWallis nonparametric test. The differences were considered as 


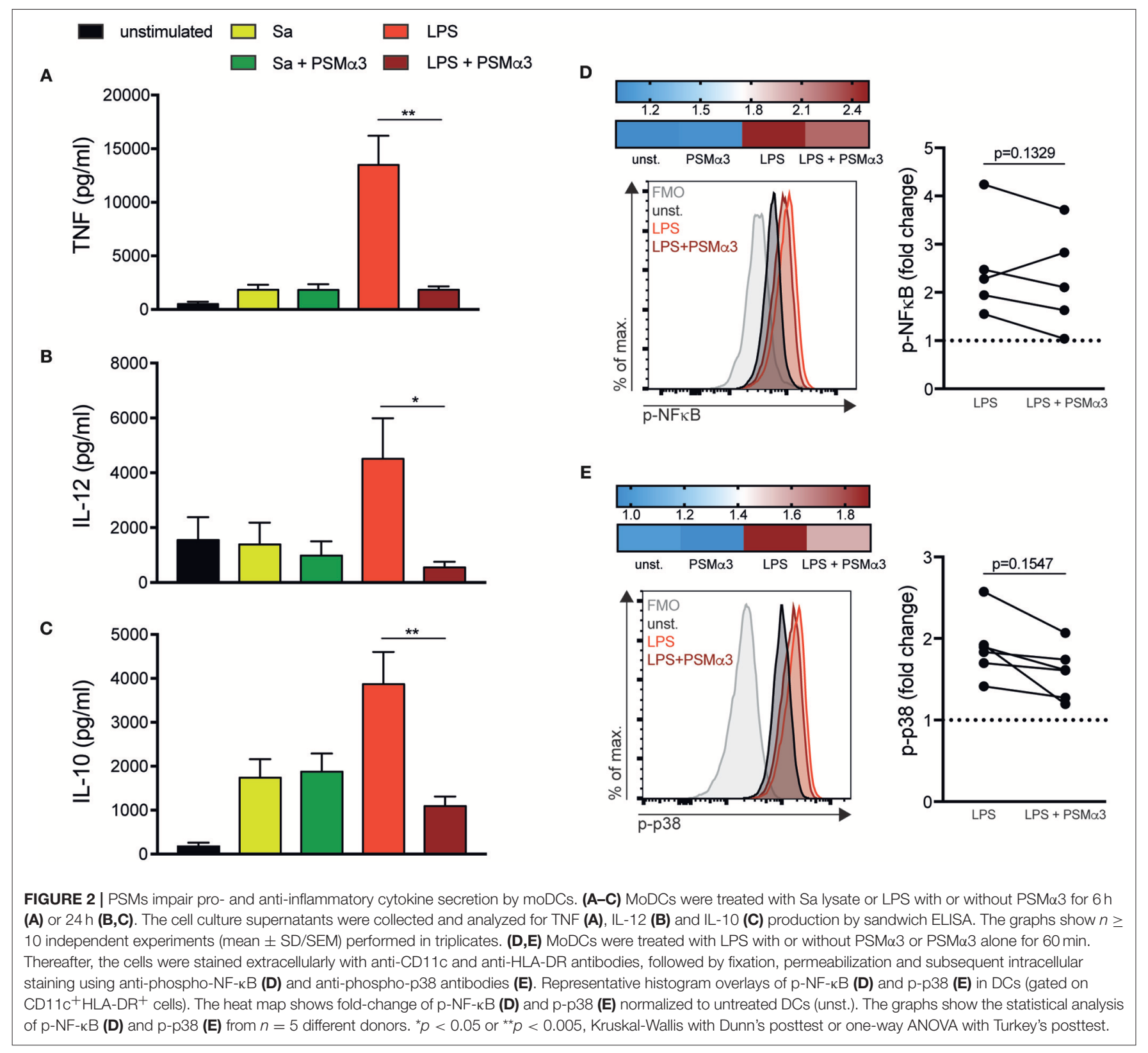

statistically significant if $p<0.05\left(^{*}\right), p<0.005\left({ }^{* *}\right), p<0.001$ $\left.{ }^{* * *}\right)$, or $p<0.0001\left(^{* * * *}\right)$.

\section{RESULTS}

\section{PSMs Modulate Surface Molecule Expression of TLR-Treated moDCs}

The maturation of DCs is an essential event for successful T-cell activation comprising the upregulation of maturation markers (e.g., CD83 and HLA-DR), co-stimulatory (e.g., CD80, CD86, CD40) and co-inhibitory molecules (e.g., PD-L1, PD-L2 or ILT3). To investigate if the Sa-derived toxin PSM $\alpha 3$ has an impact on DC maturation, moDCs were treated with either the TLR2 ligand Sa lysate (12) or the TLR4 ligand LPS with or without PSM $\alpha 3$.
Surface marker expression was analyzed by flow cytometry after 6 or 24 h (Gating see Figure S1). All surface molecules analyzed were increased upon TLRL treatment compared to untreated moDCs at 6 and $24 \mathrm{~h}$ with the exception of CD80 after $6 \mathrm{~h}$ (Figure 1) confirming DC maturation (mDCs - mature DCs). Simultaneous treatment of moDCs with TLRLs and PSM $\alpha 3$ for $6 \mathrm{~h}$ revealed a tendency, but no significant increase of the maturation marker CD83 and CD86 compared to treatment with TLRLs alone (Figure 1A). In contrast, HLA-DR was significantly increased 6h (Sa $p=0.0081$; LPS $p=0.0226$ ) after TLRL treatment in combination with PSM $\alpha 3$ whereas CD 40 was less expressed on mDCs treated with LPS in combination with PSM $\alpha 3$ compared to LPS treated cells after 6 h (LPS $p<0.0001$ ) and $24 \mathrm{~h}$ (LPS $p<0.0049$ ) (Figures 1A,B). Similarly, CD80 


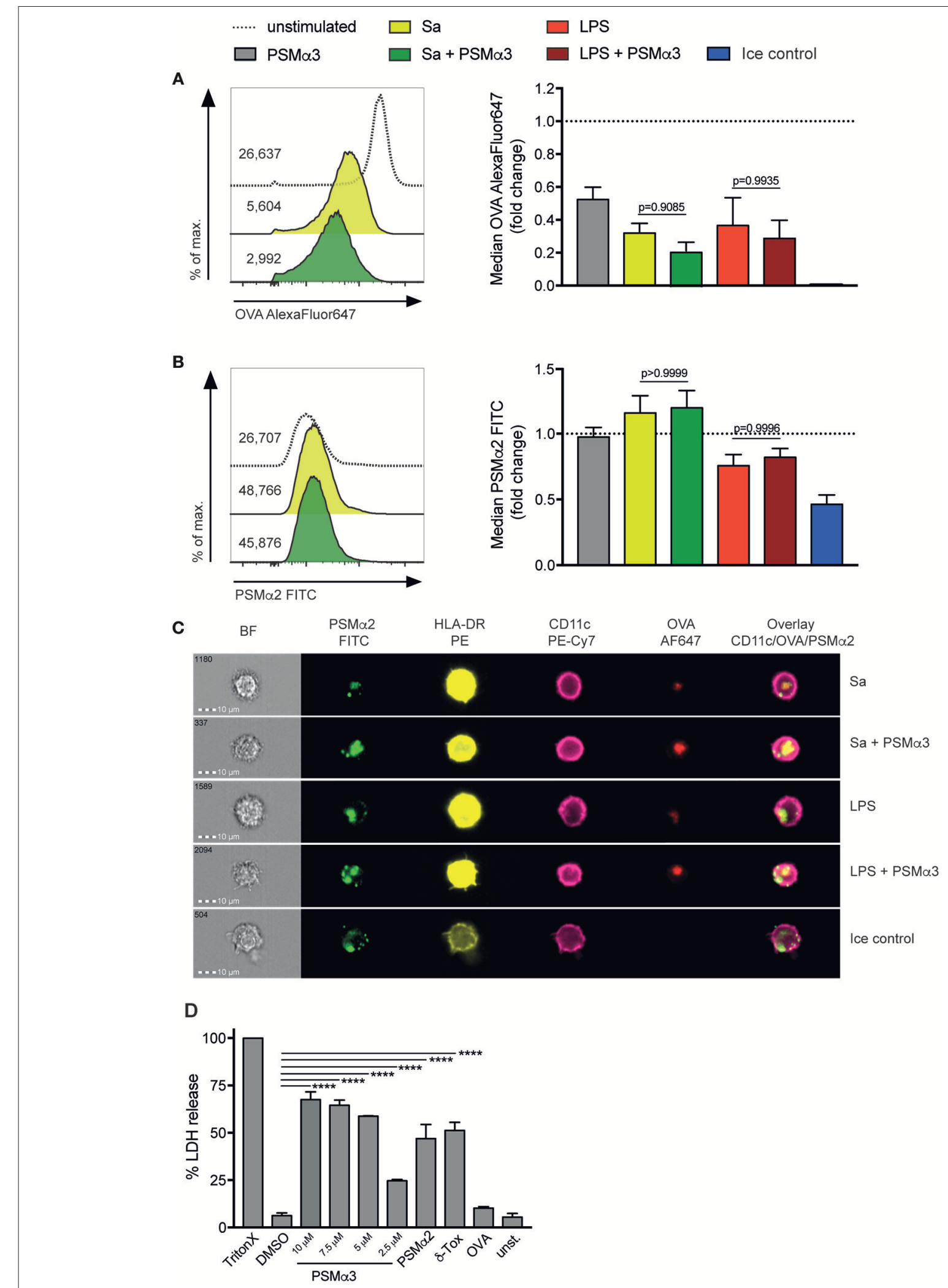

FIGURE 3 | PSMs inhibit antigen uptake by moDCs and penetrate the membrane via transient pore formation. (A-C) MoDCs treated for $24 \mathrm{~h}$ with Sa lysate or LPS with or without PSM $\alpha 3$ or PSM $\alpha 3$ alone were incubated with AlexaFluor647-labeled OVA and FITC-labeled PSM $\alpha 2$ at $37^{\circ} \mathrm{C}$ or on ice for 30 min. (A,B) The uptake of (Continued) 
FIGURE 3 | OVA and PSM $\alpha 2$ by living CD11 $\mathrm{C}^{+} \mathrm{HLA}-\mathrm{DR}^{+}$moDCs was assessed by flow cytometry. The histogram overlays (left) and the bar graphs (right, collected data) show the mean fluorescence intensity of OVA-AlexaFluor647 (A) or PSM $\alpha 2$-FITC (B), in case of the collected data as fold change of unstimulated cells $(n \geq 5$, performed in triplicates, mean \pm SEM). (C) The localization of OVA-AlexaFluor647 and PSM $\alpha 2-F I T C$ in CD11 ${ }^{+} \mathrm{HLA}^{-D R^{+}}$moDCs was analyzed by multispectral imaging flow cytometry (one representative experiment of $n=3$ independent experiments; mean \pm SEM). Representative bright field (BF) and fluorescence images of moDCs are shown for the different treatments. (D) MoDCs were either not treated (unst.) or incubated with $1 \%$ Triton X-100, $2 \%$ DMSO, PSMa3 (2.5 $\mu \mathrm{M}, 5 \mu \mathrm{M}$, $7.5 \mu \mathrm{M}$ or $10 \mu \mathrm{M}$ ), $10 \mu \mathrm{M}$ PSM $\alpha 2,10 \mu \mathrm{M} \delta$-Toxin or $5 \mu \mathrm{g} / \mathrm{mL}$ OVA for $10 \mathrm{~min}$. The LDH release was determined in the cell culture supernatants (one representative experiment of $n=3$ independent experiments; mean \pm SEM). ${ }^{* \star *} p<0.0001$, one-way ANOVA with Turkey's posttest or Kruskal-Wallis with Dunn's posttest.

up-regulation on TLR4-stimulated mDCs was impaired when the cells were treated with PSM $\alpha 3$ for 24 h (LPS $p=0.0135$ ) (Figure 1B). The analysis of co-inhibitory molecule expression revealed no significant differences after $24 \mathrm{~h}$; however, PSM $\alpha 3$ showed a tendency to prevent the upregulation of the coinhibitory molecule PD-L1 in TLR4-stimulated moDCs (LPS $p=0.0615$ ) (Figure 1C). In summary, PSM $\alpha 3$ enhanced the early upregulation of HLA-DR on DCs but prevented that of the costimulatory molecules CD40 and CD80 especially upon TLR4 stimulation.

\section{PSMs Impair Pro- and Anti-inflammatory Cytokine Secretion by TLR4-Treated moDCs}

Stimulation of TLRs not only leads to DC maturation but also to the expression of cytokines to initiate an immune response. Previously, we showed that PSM $\alpha 3$ impaired the proinflammatory cytokine production triggered by various TLRLs in mouse BM-DCs, whereas it induced the expression of the anti-inflammatory cytokine IL-10 $(12,18)$. Therefore, cell culture supernatants from moDCs treated with Sa lysate or LPS with or without PSM $\alpha 3$ were analyzed after $6 \mathrm{~h}$ for TNF (Figure 2A) and after $24 \mathrm{~h}$ for IL-12 (Figure 2B), IL-10 (Figure 2C) or TNF production (Figure S2A). TLRL treatment led to an overall induction of cytokine secretion with the exception of IL12 (Figure 2B) in TLR2-ligand treated mDCs (Figure 2). The production of TNF, IL-12 and IL-10 was impaired by PSM $\alpha 3$ in LPS treated mDCs (TNF 1.800 vs. $13.500 \mathrm{pg} / \mathrm{ml}, p=0.0082$; IL12550 vs. $4.500 \mathrm{pg} / \mathrm{ml}, p=0.021$; IL-10 1090 vs. $3850 \mathrm{pg} / \mathrm{ml}$, $p=0.0080$ ) (Figure 2) the latter in a concentration dependent manner (Figure S2B), but not in Sa lysate treated mDCs. The treatment of DCs with PSM $\alpha 3$ in combination with other TLRligands like Pam2CSK4, Pam3CSK4, LTA, Flagellin, CpG, and Imiquimod showed no significant differences in the production of TNF and IL-10 compared to TLR-L treatment alone (Figure 2 and Figure S2C). In summary, PSM $\alpha 3$ inhibited pro- as well as anti-inflammatory cytokine production by LPS-treated mDCs.

\section{PSMs Impair NF-kB and p38 Phosphorylation in LPS-Treated moDCs}

To investigate the signaling pathways involved in the cytokine modulation by PSMs, DCs were treated with LPS in the presence or absence of PSM $\alpha 3$ for $60 \mathrm{~min}$ and phosphorylation

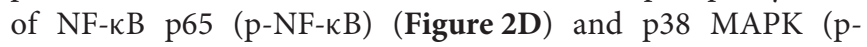
p38) (Figure 2E) was analyzed by flow cytometry. Treatment of DCs with PSM $\alpha 3$ did not affect p- NF- $\mathrm{B}$ or p-p38 compared to untreated DCs (Figures 2D,E heatmap), whereas after LPS treatment a 2.5-fold and 2-fold increase of p- NF- $\mathrm{kB}$ and p-p38, respectively, was observed compared to untreated DCs (Figures 2D,E). DCs incubated with LPS combined with PSM $\alpha 3$ revealed a 2.0-fold and 1.5-fold increase of NF- $\mathrm{KB}$ or p38 phosphorylation (Figures 2D,E). Analyzing signaling pathways in moDCs from 5 donors revealed by trend a reduced, but not significant, NF- $\mathrm{kB}$ or p38 phosphorylation upon PSM $\alpha 3$ treatment. These data indicate that impaired phosphorylation of both NF-kB and p38 pathways by PSM $\alpha 3$ may account for impaired cytokine production as well as co-stimulatory molecule expression by moDCs upon LPS treatment.

\section{PSMs Inhibit Antigen Uptake by moDCs}

Antigen uptake is a pivotal task of DCs and necessary for T-cell activation. To elucidate possible effects of PSMs on this event, moDCs were treated with or without either Sa lysate or LPS in the presence or absence of PSM $\alpha 3$ for $24 \mathrm{~h}$. Subsequently cells were incubated with the fluorescently-labeled (AlexaFluor647) model antigen OVA in combination with FITClabeled PSM $\alpha 2$ for $30 \mathrm{~min}$. Immature DCs (iDCs - immature DCs) take up OVA mainly by clathrin-mediated endocytosis and macropinocytosis, whereas mature DCs retain antigen uptake by receptor-mediated endocytosis $(12,19-21)$. This effect was observed when moDCs matured after treatment with either Sa lysate or LPS by $\sim 68$ or $\sim 63 \%$, respectively (Figure $3 \mathrm{~A}$ ). OVA uptake was reduced by $\sim 48 \%$ after solely treatment with PSM $\alpha 3$ ( $p<0.0001)$ (Figure 3A), showing that iDCs are affected in their task to take up antigen by PSMs. A trend to further impaired antigen uptake by TLRL and PSM $\alpha 3$ treated moDCs was observed (Sa $p=0.6603$, LSP $p=0.9054$ ) (Figure 3A). Incubation of iDCs with OVA on ice was used to exclude unspecific binding (Figure 3A) thereby preventing remodeling of the actin cytoskeleton, which is required for clathrin-mediated endocytosis and micropinocytosis (22). In conclusion, PSM $\alpha 3$ affects moDCs in their antigen uptake capacity.

\section{PSMs Penetrate the Membrane of moDCs Via Transient Pore Formation}

Previously, we and others showed that PSMs form transient pores into the cell membrane thereby entering the cytosol $(10,15)$. To address whether PSMs are internalized by human moDCs via mechanisms of antigen uptake or by pore formation iDCs were incubated with fluorescently-labeled PSM $\alpha 2$ as described above and analyzed by flow cytometry and multispectral imaging flow cytometry. Despite the uptake of OVA-AlexaFluor647, PSM $\alpha 2$ FITC was observed in moDCs regardless of their maturation 


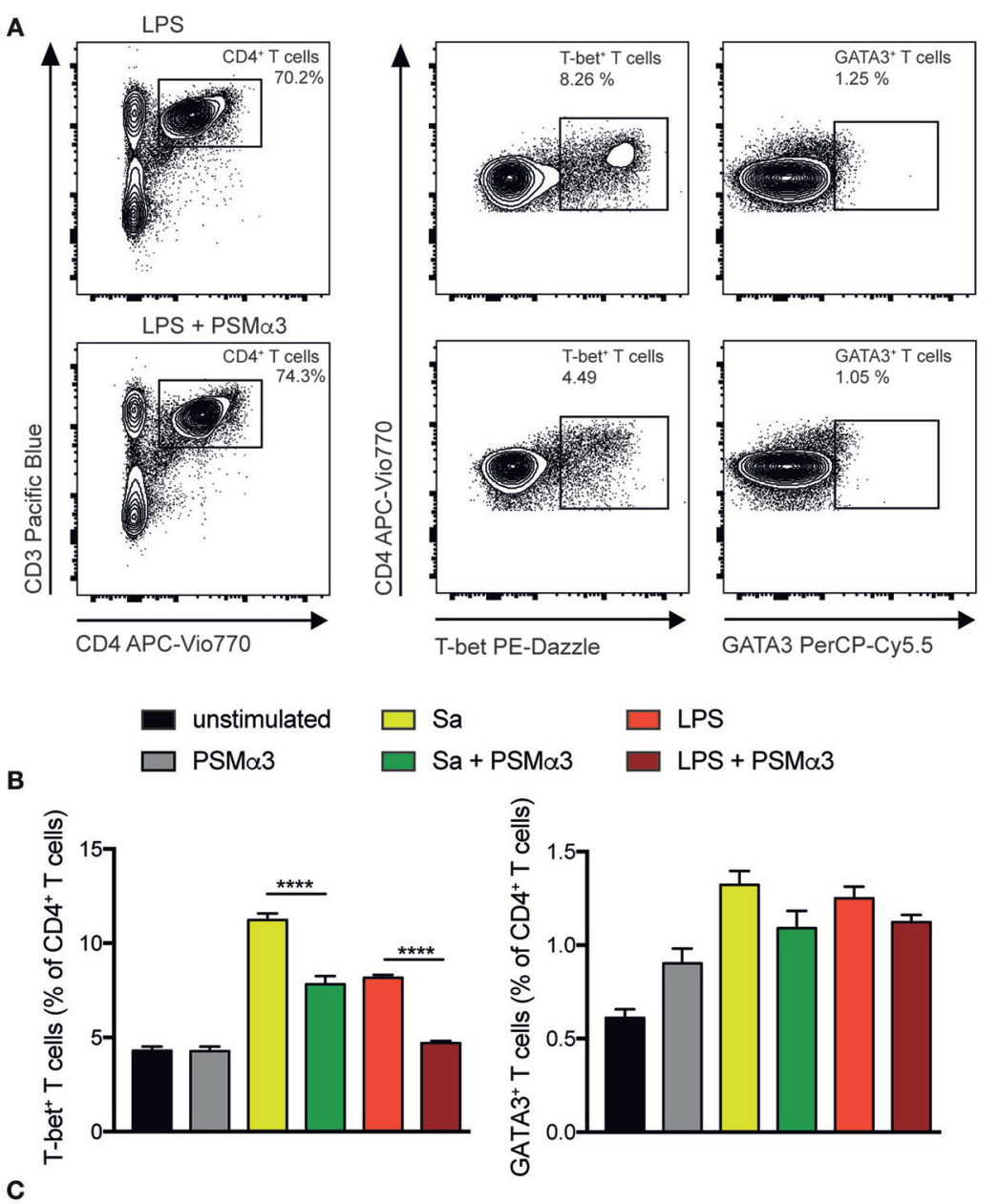

C
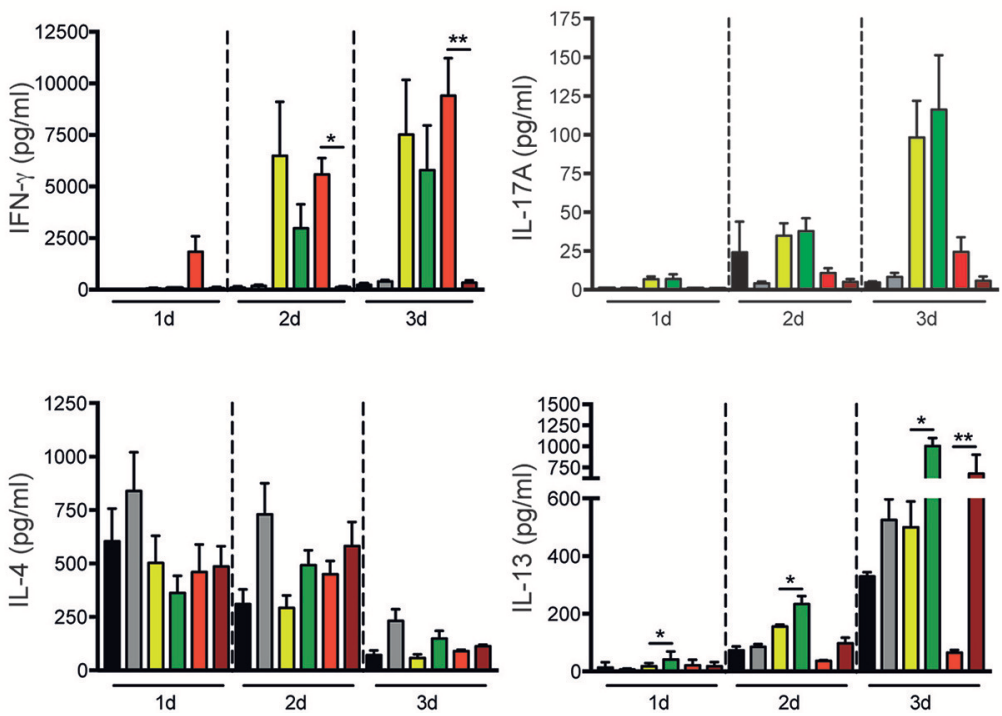

FIGURE 4 | Polarization of Th1 is impaired by PSMs. MoDCs treated for $24 \mathrm{~h}$ with Sa lysate or LPS with or without PSM $\alpha 3$ or PSM $\alpha 3$ alone were co-cultured with CFSE-labeled naiive CD4 ${ }^{+}$T cells for $3 \mathrm{~d}$. The different Th subsets were analyzed by flow cytometry; Th1 cells were characterized as CD3 ${ }^{+} \mathrm{CD} 4{ }^{+} \mathrm{T}_{\text {-bet }}{ }^{+} \mathrm{T}$ cells, Th2 cells were characterized as $\mathrm{CD} 3^{+} \mathrm{CD} 4^{+} \mathrm{GATA}^{+} \mathrm{T}$ cells $(\mathbf{A})$. (B) The bar graphs show the frequency of T-bet ${ }^{+}$Th1 and GATA3 $^{+}$Th2 cells from CD4 ${ }^{+} \mathrm{T}_{\text {cells }}$ (one representative of $n=4$ independent experiments performed in triplicates, mean \pm SEM). (C) Cell culture supernatants from the DC T cell co-culture were collected after $1 \mathrm{~d}, 2 \mathrm{~d}$ or $3 \mathrm{~d}$ and analyzed for Th-associated cytokine production $(n \geq 3$ performed in triplicates; mean $\pm \mathrm{SEM})$. ${ }^{\star} p<0.05$, ${ }^{* *} p<0.005$, or ${ }^{\star \star \star *} p<0.0001$, one-way ANOVA with Turkey's posttest or Kruskal-Wallis with Dunn's posttest. 


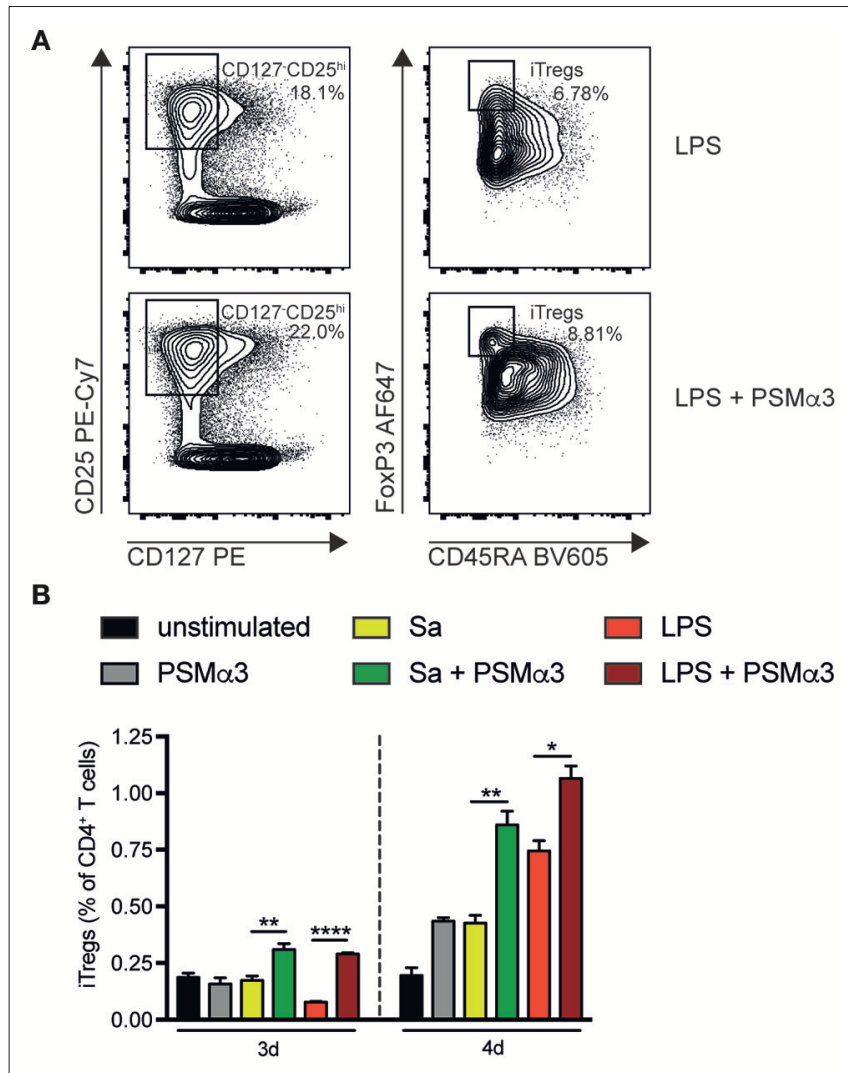

C

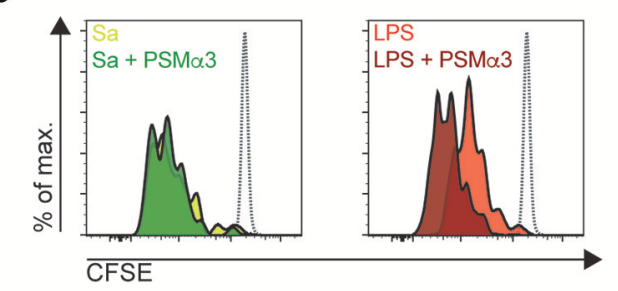

D
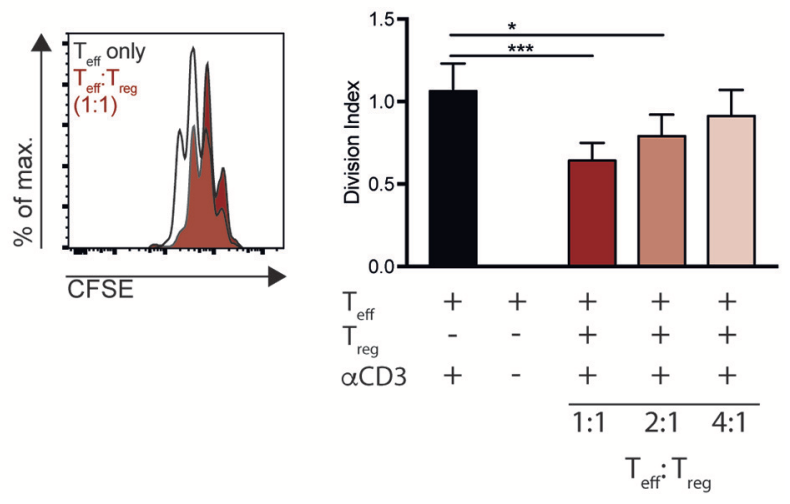

FIGURE 5 | PSM $\alpha 3$-treated moDCs increase the proliferation and frequency of $\mathrm{iT}_{\text {regs. }}$ (A-C) MoDCs treated for $24 \mathrm{~h}$ with Sa lysate or LPS with or without $\mathrm{PSM} \alpha 3$ or PSM $\alpha 3$ alone were co-cultured with CFSE-labeled naïve $\mathrm{CD}^{+}{ }^{+} \mathrm{T}$ cells for $3 \mathrm{~d}$ or $4 \mathrm{~d}$. iT regs were analyzed by flow cytometry and characterized as $\mathrm{CD} 4{ }^{+} \mathrm{CD} 127^{-} \mathrm{CD} 25^{\text {hi }} \mathrm{CD} 45 \mathrm{RA}{ }^{-}$Foxp3 $3^{\text {hi }}$ cells (A). The frequency of $\mathrm{iT}$ regs from $\mathrm{CD}^{+}{ }^{+} \mathrm{T}$ cells $\mathbf{( B )}$ and the proliferation of $\mathrm{iT}_{\text {regs }}$ (C) co-cultured with TLRL-only or in combination with PSM $\alpha 3$-treated $\mathrm{mDC}$ s was analyzed (n $\geq 5$ performed in triplicates, mean \pm SEM). Proliferation was compared to $T$ cells

(Continued)
FIGURE 5 | cultured without DCs (gray dotted line). (D) Allogenic suppression assay of CFSE-labeled $T_{\text {effs }}$ cultured in different ratios with or without sorted Tregs (CD4 ${ }^{+} \mathrm{CD} 127^{-} \mathrm{CD} 25^{\mathrm{hi}} \mathrm{CD} 45 \mathrm{RA}^{-}$, Figure S7) from DC T cell co-culture described in (A). Proliferation of the CFSE-labeled $\mathrm{T}_{\text {effs }}$ with or without activation via $\alpha$ CD3-beads was assessed after $3 \mathrm{~d}(n=2$ performed in triplicates; mean \pm SEM). ${ }^{*} p<0.05,{ }^{\star *} p<0.005,{ }^{* \star *} p<0.001$, or ${ }^{\star \star \star \star} p<$ 0.0001 , one-way ANOVA with Turkey's posttest or Kruskal-Wallis with Dunn's posttest.

status (Figure 3B). Moreover, PSM $\alpha 2$-FITC was also detected in moDCs incubated on ice but reduced by $\sim 54 \%$ ( $p=$ $0.0003)$, indicating that the uptake was not an active process requiring actin remodeling (Figure 3B). These observations were confirmed by multispectral imaging flow cytometry, showing PSM $\alpha 2$-FITC located at the membrane when actin-cytoskeleton rearrangement is blocked (ice control) as well as co-localized with OVA most likely in the phagosome when moDCs were incubated at $37^{\circ} \mathrm{C}$ regardless of the treatment (Figure $3 \mathrm{C}$ ).

Transient pore formation in the membrane of moDCs mediated by PSM $\alpha 3$ was demonstrated by measuring L-lactate dehydrogenase (LDH) in the supernatant of moDCs treated with PSM $\alpha 2$ various concentrations of PSM $\alpha 3$ (Figure 3D). Triton$\mathrm{X}$, which disrupts the membrane completely as well as $\delta$-Toxin, which is known to form transient pores (23) were used as positive controls (Figure 3D). Neither treatment of moDCs with OVA, the peptide-dissolvent DMSO or medium alone had any effects on LDH release (Figure 3D), whereas PSM $\alpha 3$ significantly induced LDH release in a concentration-dependent manner. Further, flow cytometric analysis of the moDCs showed that apart from treatment with Triton-X, none of the reagents affected their viability (Figure S3). Together the data show that PSMs enter moDCs via transient pore formation without cytolytic effects.

\section{Polarization of T Helper1 Cells Is Impaired by PSMs}

DCs play a crucial role in the activation and polarization of $\mathrm{T}$ cells. Not only the direct interaction, but also the local cytokine milieu is important for the outcome and distinct transcription factors control the differentiation of the $\mathrm{T}$ cell subsets $(24,25)$. To assess the impact of PSM $\alpha 3$-treated moDCs on the polarization of $\mathrm{T}$ helper (Th) cell subsets, moDCs were treated with or without Sa lysate or LPS in combination with PSM $\alpha 3$ for $24 \mathrm{~h}$. Subsequently, the cells were co-cultured with naive $\mathrm{CD} 4^{+} \mathrm{T}$ cells for 3-4 d. Flow cytometry analysis of the Th subsets showed that TLRL-treated mDCs primed significantly more T-bet ${ }^{+}$Th1 cells whereas mDCs co-treated with PSM $\alpha 3$ prevented Th1 priming (Sa 11.2 vs. $7.8 \%, p<0.0001$; LPS 8.2 vs. $4.7 \%, p<$ 0.0001) (Figures 4A,B). In contrast, stimulation of iDCs with PSM $\alpha 3$ alone did not show any difference compared to untreated cells (Figure 4B), indicating that PSM $\alpha 3$ without TLRL has no influence on the priming capacity of moDCs. Analyzing Th2 cells by GATA3 expression after co-culture with moDCs treated with TLRL alone or in combination with PSM $\alpha 3$ revealed the same tendency as T-bet expression, but no significant differences ( $\mathrm{Sa}$ 1.32 vs. $1.1 \%, p=0.27$; LPS 1.25 vs. $1.1 \%, p=0.8$ ) (Figures 4 A,B 
and Figure S6B). However, no difference in the frequency of $\mathrm{ROR} \gamma \mathrm{t}^{+} \mathrm{CD} 4^{+} \mathrm{T}$ cells was observed (data not shown).

Cytokine secretion analysis of the major Th1, Th2, and Th17 cytokines in co-culture after 1-3 days showed that IFN$\gamma$ secretion was completely prevented when TLR4 ligand-treated $\mathrm{mDCs}$ were co-treated with PSM $\alpha 3$ (LPS day $11.800 \mathrm{vs.} 80 \mathrm{pg} / \mathrm{ml}$, $p=0.5617$; day 25.600 vs. $120 \mathrm{pg} / \mathrm{ml}, p=0.0146$, day 39.400 vs. $330 \mathrm{pg} / \mathrm{ml}, p<0.0001$ ), which in part, but not significant, was also seen for TLR2-stimulated mDCs (Sa day 160 vs. $40 \mathrm{pg} / \mathrm{ml}$, $\mathrm{p}>0.999$; day 26.500 vs. $3.000 \mathrm{pg} / \mathrm{ml}, p=0.2534$, day 37.500 vs. $5,800 \mathrm{pg} / \mathrm{ml}, p=0.9105$ ) (Figure $4 \mathrm{C}$ ). Comparable results, but without significance, were observed for IL-17A secretion at day 2 and 3 by TLR4 ligand-treated mDCs together with PSM $\alpha 3$ (LPS day 210.8 vs. $5.1 \mathrm{pg} / \mathrm{ml}, p=0.9658$, day3 24.4 vs. 5.7 $\mathrm{pg} / \mathrm{ml}, p=0.4336)$. Similarly, no significant effects of PSM $\alpha 3$ were observed for IL-17A secretion after co-culture of $\mathrm{CD} 4^{+} \mathrm{T}$ cells with mDCs treated with Sa lysate. Further, IL-4 secretion showed no difference after treatment with either Sa lysate or LPS, respectively (Figure 4C). However, the expression of the closely related cytokine IL-13 significantly increased 3 days after coculture of $\mathrm{CD} 4^{+} \mathrm{T}$ cells with moDCs treated with TLRLs and PSM $\alpha 3$ (Sa 500 vs. $1.000 \mathrm{pg} / \mathrm{ml}, p=0.0327$; LPS 65 vs. 680 $\mathrm{pg} / \mathrm{ml}, p=0.0057$ ) (Figure 4C). This Th cytokine expression is connected with the impaired production of pro-inflammatory cytokines in co-cultures of $\mathrm{CD}^{+} \mathrm{T}$ cells with moDCs treated with TLRLs and PSM $\alpha 3$ (Figures S5A-C).

Thus, PSM $\alpha 3$-treated TLR2- and TLR4- stimulated mDCs decreased the frequency of T-bet ${ }^{+}$Th1 cells, as well as IFN- $\gamma$ secretion.

\section{PSM $\alpha 3-T r e a t e d$ moDCs Induce $\mathbf{T}_{\text {reg }}$ Priming Via Direct Cell Interaction and IDO Production}

Previously, our group showed that PSM $\alpha 3$ primes mouse tDCs thereby enhancing the frequency and proliferation of $\mathrm{T}_{\text {regs }}$ $(10,12)$. Further, as PSM $\alpha 3$ treatment of moDCs attenuated the priming of Th1 cells, we investigated whether PSM $\alpha 3$ treated moDCs also increased $\mathrm{T}_{\text {reg }}$ priming. Therefore, moDCs were treated with or without Sa lysate or LPS in combination with PSM $\alpha 3$ for $24 \mathrm{~h}$. Next, the cells were co-cultured with naïve CFSE-labeled $\mathrm{CD}^{+} \mathrm{T}$ cells for 3-4 $\mathrm{d}$ and analyzed by flow cytometry. Newly primed $\mathrm{T}_{\text {regs }}$ were characterized as $\mathrm{CD}^{+}{ }^{+} \mathrm{CD} 127^{-} \mathrm{CD} 25^{\text {hi }} \mathrm{CD} 45 \mathrm{RA}^{-}$FoxP $3{ }^{\text {hi }}$ induced $\mathrm{T}_{\text {regs }}\left[\mathrm{iT}_{\text {regs }}\right.$; (26)]. PSM $\alpha 3$ increased the frequency of $\mathrm{iT}_{\text {regs }}$ upon co-culture with moDCs after TLR2 or TLR4 ligand treatment (Sa day 30.17 vs. $0.31 \%, p<0.0033$; Sa day 40.43 vs. $0.86 \%, p=0.0054$; LPS day 30.08 vs. $0.29 \%, p<0.0001$; LPS day 40.75 vs. $1.07 \%, p=$ 0.0204) (Figures 5A,B). Treating $\mathrm{CD} 4^{+} \mathrm{T}$ cells with PSM $\alpha 3$ in combination with TLRLs without moDCs did not result in $\mathrm{CD} 4^{+}$ $\mathrm{T}$ cell activation or priming of $\mathrm{iT}_{\text {regs }}$ (Figure $\mathrm{S6}$ ).

Further, these $\mathrm{iT}_{\text {regs }}$ showed a greater proliferation potential than the $i \mathrm{~T}_{\text {regs }}$ primed without PSM $\alpha 3$ (Figure 5C). To test the functionality of these $\mathrm{iT}_{\text {regs }}$, we sorted $\mathrm{iT}_{\text {regs }}$ $\left(\mathrm{CD} 4{ }^{+} \mathrm{CD} 127^{-} \mathrm{CD} 25^{\mathrm{hi}} \mathrm{CD} 45 \mathrm{RA}^{-}\right)$after $4 \mathrm{~d}$ of co-culture with LPS + PSM $\alpha 3$-treated moDCs (Figure S7). Sorted $\mathrm{iT}_{\text {regs }}$ were again cultured with CFSE-labeled $\mathrm{CD}^{+} \mathrm{T}$ cells $\left(\mathrm{T}_{\text {eff }}\right.$ ) in the presence of anti-CD3/CD28 coated beads to induce $\mathrm{T}_{\text {eff }}$ proliferation for $4 \mathrm{~d}$. $\mathrm{T}_{\text {regs }}$ significantly decreased $\mathrm{T}_{\text {eff }}$ proliferation analyzed by CFSE-dilution in a concentrationdependent manner $(1: 1$ reduction $\sim 38 \%, p=0.0004 ; 1: 2$ reduction $\sim 25 \%, p=0.0176 ; 1: 4$ reduction $\sim 12 \%, p=0.2603$ ) (Figure 5D), demonstrating that PSM $\alpha 3$-induced $\mathrm{iT}_{\text {regs }}$ suppress $\mathrm{T}_{\text {eff }}$ proliferation.

To investigate whether secreted factors from DCs upon PSM-treatment mediate $\mathrm{i}_{\text {reg }}$ priming, $\mathrm{T}$ cells were co-cultured with iDCs simultaneously adding medium from LPS or LPS with PSM $\alpha 3$-treated moDCs (conditioned medium) (Figure 6A condition 2). As described above, PSM $\alpha 3$ increased the frequency of $\mathrm{iT}_{\text {regs }}$ upon co-culture of naïve $\mathrm{CD} 4^{+} \mathrm{T}$ cells with moDCs (Figure 6A condition 1 and Figure 6B). A similar increase of $i T_{\text {regs }}$ was mediated by iDCs incubated with conditioned medium from LPS + PSM $\alpha 3$, whereas LPS conditioned medium had no effect $(0.31 \%$ compared to $0.09 \%$, respectively, $p=0.0757)$ Figure 6A condition 2 and Figure 6B). These observations show that PSM-induced secretion of soluble factors by mDCs modulate iDCs to prime $\mathrm{iT}_{\text {regs. }}$.

In another assay DCs were washed $24 \mathrm{~h}$ after treatment with LPS or LPS + PSM $\alpha 3$ (mDCs) and further cultured for 3-4 days with $\mathrm{CD} 4^{+} \mathrm{T}$ cells in fresh medium. These conditions revealed an even higher frequency of $\mathrm{iT}_{\text {regs }}(0.52$ or $1.32 \%$, respectively; $p<$ 0.0001 ) compared to mDCs without medium change (Figure 6A condition 3 and Figure 6B) and suggest that the interaction of mDCs with $\mathrm{CD}^{+} \mathrm{T}$ cells as well as secreted factors produced by $\mathrm{mDCs}$ after interaction with $\mathrm{T}$ cells are important for $\mathrm{iT}_{\text {reg }}$ priming.

To further address the impact of direct DC-T-cell interaction on $\mathrm{T}_{\text {reg }}$ priming, $\mathrm{mDC}$ were fixed and either cultured with naïve $\mathrm{CD} 4^{+} \mathrm{T}$ cells in fresh or conditioned medium. Fixation of $\mathrm{mDC}$ s treated with or without PSM $\alpha 3$ led to low frequencies of $\mathrm{iT}_{\text {regs }}$ after co-culture with naïve $\mathrm{CD}^{+} \mathrm{T}$ cells in fresh medium $(0.08 \%$ vs. $0.2 \%, p=0.6038$ ) (Figure $6 \mathrm{~A}$ condition 4 and Figure 6B). Similar results were obtained by the addition of conditioned medium to this co-culture showing that mainly direct interaction of $\mathrm{mDC}$ s with naïve $\mathrm{CD} 4^{+} \mathrm{T}$ cells is essential for $\mathrm{iT}_{\text {reg }}$ induction. However, in this experimental setting we cannot exclude that soluble factors produced by mDCs after DC$\mathrm{T}$ cell interaction are involved in $\mathrm{iT}_{\text {reg }}$ priming. To address this issue, culture supernatants of $\mathrm{mDCs}$ with naïve $\mathrm{CD} 4^{+} \mathrm{T}$ cells were analyzed over time for soluble factors, which were shown to be responsible for $\mathrm{iT}_{\text {reg }}$ priming and proliferation, like TGF- $\beta$, IL10, IL-2, CD40L and IDO. Neither, IL-10 (Figure 6C), TGF- $\beta$ (Figure 6D), CD40L nor IL-2 (Figure S5 were increased in the co-culture of PSM $\alpha 3$-treated $\mathrm{mDCs}$ with naïve $\mathrm{CD} 4^{+} \mathrm{T}$ cells compared to mDCs independently of the TLRL used. Moreover, T helper cell priming cytokines like IL-4, IL-6, IL-12p70, IL17A and IFN- $\gamma$ were hardly detectable in the co-culture supernatants of LPS + PSM $\alpha 3$ treated mDCs with $\mathrm{CD}^{+}{ }^{+} \mathrm{T}$ cells (Figure $4 \mathrm{C}$ and Figure S5) as described above.

In contrast, secretion of the enzyme IDO, which is important for $\mathrm{T}_{\text {reg }}$ differentiation from naïve $\mathrm{T}$ cells (8), was significantly increased by $\mathrm{mDCs}$ in response to PSM $\alpha 3$ treatment after 1 (11.000 vs. $1.440 \mathrm{pg} / \mathrm{ml}, p<0.0001)$ and 2 days (42.000 vs. $33.800 \mathrm{pg} / \mathrm{ml}, p=0.0006$ ) compared to $\mathrm{mDCs}$ alone (Figure 6E). 
As previously described, LPS treatment alone also led to IDO secretion by moDCs (27). We addressed the impact of IDO on $\mathrm{iT}_{\text {reg }}$ priming by $\mathrm{mDC}$ using the specific IDO inhibitor 1-Methyl-D-Tryptophan (1-DMT) prior to treatment of iDCs with LPS or LPS + PSM $\alpha 3$. These mDCs were then co-cultured with $\mathrm{CD}^{+} \mathrm{T}$ cells and the frequency of $\mathrm{iT}_{\text {regs }}$ determined as described above. Surprisingly, IDO inhibition revealed increased frequencies of $\mathrm{iT}_{\text {regs }}$ by 2 fold independently whether cells were treated with LPS + PSM $\alpha 3$ or the inhibitor alone (see Figure S8). No difference in the proliferation of $\mathrm{CD} 4^{+} \mathrm{T}$ cells was observed upon IDO inhibition. Moreover, IDO inhibition had hardly any effect on the frequency of Th1, Th2 and Th17 cells in the culture (data not shown). Thus, the increased IDO production by PSMtreated DCs seems not to be essential for $\mathrm{iT}_{\text {reg }}$ induction.

Together, these data indicate that PSM $\alpha 3$ modulates moDCs to prime predominantly $\mathrm{T}_{\text {regs }}$ via mechanisms involving mainly direct DC-T cell interaction in combination with DC-secreted yet unknown factors.

\section{PSM $\alpha 3-$ Treated moDCs Induce $T_{\text {regs }}$ From $\mathrm{CD4}^{+} \mathrm{T}$ Cells of Patients With Autoimmune Diseases}

In order to address whether PSM $\alpha 3$ can be used for therapeutic approaches by modulating moDCs for $\mathrm{iT}_{\text {reg }}$ priming in a setting of $\mathrm{T}$ cell associated autoimmune diseases, moDCs from healthy donors were co-cultured after treatment with LPS or LPS + $\mathrm{PSM} \alpha 3$ with $\mathrm{CD} 4{ }^{+} \mathrm{T}$ cells from patients with spondyloarthritis (Figure 7A) and rheumatoid arthritis (RA) (data not shown). These patients suffer from spondylitis/enthesitis of the spine or peripheral arthritis with pain, morning stiffness and consecutive ankylosing of the spine and/or joint destruction. These diseases display a high frequency of pro-inflammatory Th1 and Th17 cells. As shown for T cells from healthy donors, PSM $\alpha 3$ increased the frequency of $\mathrm{iT}_{\text {regs }}$ upon co-culture with LPS-treated $\mathrm{mDCs}$ by $>$ 10 -fold compared to LPS treatment alone $(p=0.024)$, whereas no effects were observed for Th1, Th2, and Th17 priming of T cells from patients with spondylitis (Figure 7A). Moreover, similar, but not significant results $(p=0.0919)$ could be observed in an autologous setting using $\mathrm{mDCs}$ and $\mathrm{CD} 4^{+} \mathrm{T}$ cells from patients with spondyloarthritis (Figure 7B and Figure S9). This shows that PSM $\alpha 3$ indeed modulates moDCs to prime $\mathrm{iT}_{\text {regs }}$ even in allogenic and autologous disease settings, indicating its potential for DC therapy in chronic inflammatory diseases.

\section{DISCUSSION}

There is a need for particular therapeutic approaches preventing or inhibiting immune activation in autoimmune diseases, allograft rejection, allergies, asthma and various forms of hypersensitivity. Current therapies, which mainly use nonspecific systemic immunosuppressants, are associated with severe side effects. Thus, ex vivo generated tDCs are an attractive alternative to enhance, maintain or restore immunological tolerance.

Here, we addressed the possibility of PSM $\alpha 3$, which is secreted by highly virulent CA-MRSA strains, to induce human tDCs as potential therapeutic for DC vaccination strategies. PSMs form transient pores into the membrane of neutrophils (15), and DCs thereby getting access to the cytosol, in the case of DCs without cell lysis (Figure 3) (10). Molecularly, PSM $\alpha 3$ enhanced the activation of the $\mathrm{p} 38$-CREB pathway upon TLR ligation, which in consequence diminished pro-inflammatory cytokine production but induced IL-10 secretion by mouse bone marrow-derived DCs (10). Here, we show that PSM $\alpha 2$ enters human moDCs via endocytosis and transient pore formation and is located in the cytosol as well as close to the membrane. Indeed, NF- $\kappa$ B as well as p38 activation are necessary for DC maturation including upregulation of CD80, CD86, and CD40, but also cytokine production (28-30). We believe that PSM $\alpha 3$ prevents TLRactivation either extracellularly and/or intracellularly thereby inducing tDCs. Direct extracellular interaction of PSM $\alpha 1-3$ with TLR4 was shown to prevent binding of HMGB1 to TLR4 and thus downstream activation of NF- $\mathrm{B}$ (31). Similarly, we here show that PSM $\alpha 3$ prevents activation of NF- $\kappa$ B as well as p38 MAPK signaling. Whether PSM $\alpha 3$ also blocks binding of LPS to TLR4 remains to be shown. Moreover, our findings are in agreement with several studies showing that NF- $\kappa$ B inhibition favors an immature or tolerogenic DC phenotype, which stimulates the expansion of Foxp3 expressing regulatory T cells (32-35).

A hallmark of tDCs is their immature phenotype characterized by low surface levels of MHC class II and costimulatory molecules, such as CD86, CD40, CD54, and PD-L2, but increased expression of TLRs, chemokine receptors and PD-L1. In vivo studies showed that the tissue or even tumor microenvironment is important for regulating the development and function of tDCs (36). Although PSM $\alpha 3$ had little influence on TLR-induced upregulation of HLA-DR, CD83, CD86, and PD-L2, up-regulation of costimulatory molecules CD80, PD-L1, and CD40 was inhibited, preventing full DC-maturation. Likewise, cholera toxin in combination with LPS induced CD80 and CD86 but reduced CD40 and CD54 expression by DCs (37). Mechanistically, the inhibition of $\mathrm{TNF} \alpha$ production, which among others regulates CD40 expression, upon synergistic treatment with TLRLs and PSM $\alpha 3$ could explain the impaired up-regulation of CD40 (38). This fits to the fact that the lack of CD40 expression on DCs was shown to be important for the generation of $\mathrm{T}_{\text {regs }}$ while suppressing primary immune responses (39). Moreover, some studies have shown that phenotypically mature DCs are also able to promote $\mathrm{T}_{\text {regs }}$ and act superior in activating their suppressor function $(40,41)$.

In addition, PSM $\alpha 3$ dramatically changed the cytokine secretion pattern of moDCs upon TLRL treatment by preventing the secretion of the pro-inflammatory cytokines TNF, IL-12, but also of anti-inflammatory IL-10, which is produced by DCs in response to TLR-stimulation. This is in contrast to the data observed by mouse bone-marrow derived DC, where IL10 secretion is even increased upon PSM and TLRL treatment compared to TLRL treatment alone (12). However, PSM-treated moDCs still impair Th1 but promote $\mathrm{T}_{\text {reg }}$ priming. Tolerogenic DCs are defined by their capacity to induce $\mathrm{T}_{\text {regs }}$ via production of anti-inflammatory molecules that may be secreted, membrane bound, or both. A variety of studies demonstrated the necessity of IL-10 secretion by tDCs for $\mathrm{T}_{\text {reg }}$ induction (42-45) and for the maintenance of suppressive $\mathrm{T}_{\text {regs }}$ upon strong inflammatory 


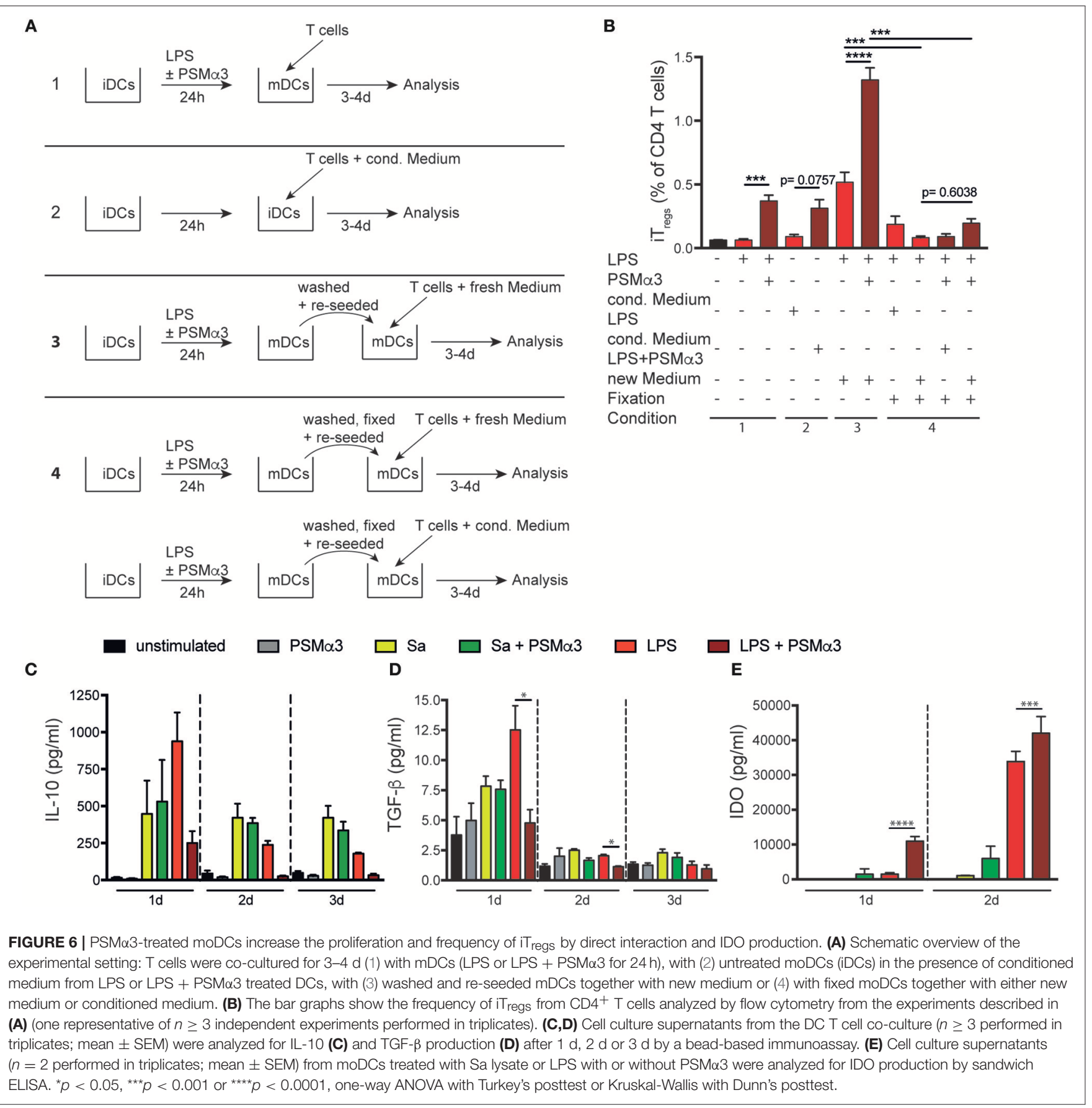

signals $(12,44,46,47)$. The data described herein raise the question whether IL-10 secretion is a hallmark of tDCs.

As T-cell differentiation is mainly controlled by cytokines mediating polarizing signals (48) we addressed other factors

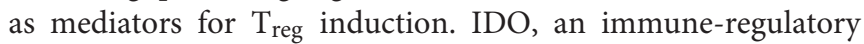
enzyme, which is mainly expressed in DCs, was shown to modulate adaptive immune responses by promoting immunesuppression and tolerance (49-51). IDO expression in DCs is induced either by IFN- $\gamma$ or by TLR activation via the non-canonical NF- $\kappa \mathrm{B}$ pathway. IDO acts through tryptophan
(TRP) depletion and production of TRP metabolites thereby inducing differentiation of new $\mathrm{T}_{\text {regs }}$ from naïve $\mathrm{T}$ cells $(27,51-$ 55). PSM treatment of moDCs resulted in an even enhanced IDO expression as compared to Sa lysate or LPS treatment alone. The latter was recently shown to induce IDO together with the transcription factor aryl-hydrocarbon receptor (AhR) (27). However, our results obtained with IDO inhibition by 1-DMT argue against a mechanistically role of IDO in PSMmediated $\mathrm{T}_{\text {reg }}$ induction. Thus, it is tempting to speculate that PSM $\alpha 3$ modulated moDCs prime $\mathrm{T}_{\text {regs }}$ via mechanisms involving 

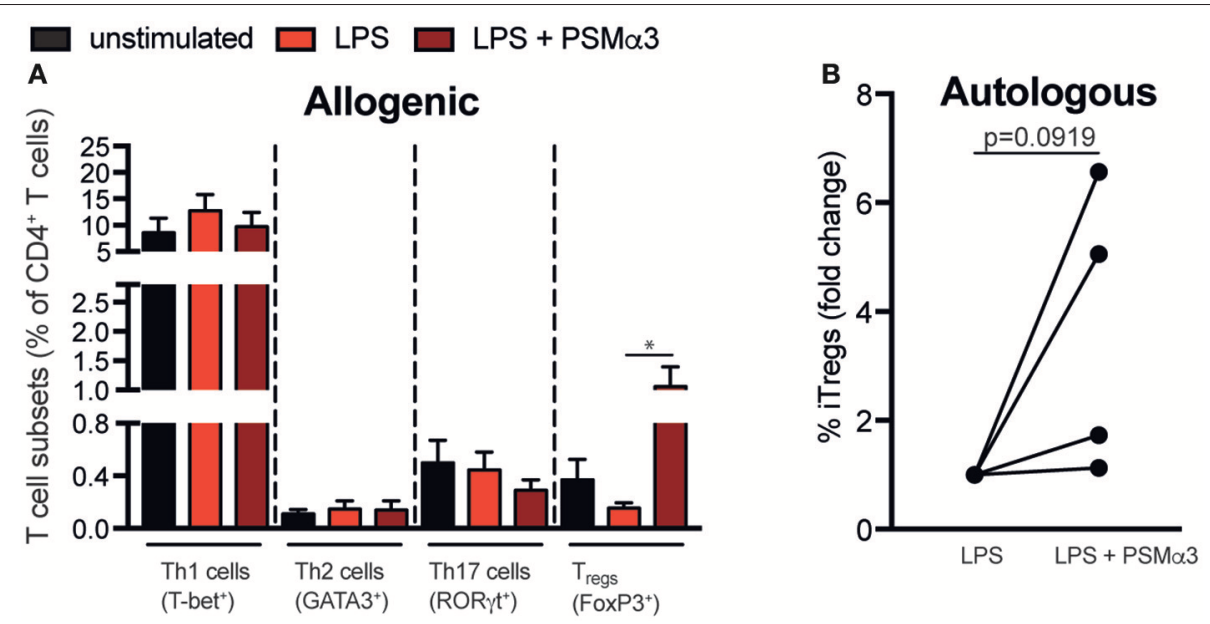

FIGURE 7 | PSMa3-treated moDCs induce $T_{\text {regs }}$ from $\mathrm{CD}^{+}{ }^{+} \mathrm{T}$ cells of patients with autoimmune diseases. (A) Allogenic T-cell assay: MoDCs from healthy donors were treated for $24 \mathrm{~h}$ with LPS with or without PSM $\alpha 3$ and co-cultured with CFSE-labeled CD4 ${ }^{+} \mathrm{T}$ cells from patients with Th17-associated spondyloarthritis for $3 \mathrm{~d}$ or $4 \mathrm{~d}$. The different $\mathrm{T}$ cell subsets were analyzed by flow cytometry. The graph shows the frequency of the T-bet ${ }^{+}$Th1, GATA3 ${ }^{+}$Th2, ROR Rt $^{+}$Th17 cells and CD127-CD25 ${ }^{\text {hi CD45RA }}{ }^{-}$Foxp3 ${ }^{\text {hi i }}{ }^{\text {iT regs from CD4 }}{ }^{+}$T cells $\left(n=6\right.$ patients; mean \pm SEM). ${ }^{*} p<0.05$, one-way ANOVA with Turkey's posttest or Kruskal-Wallis with Dunn's posttest. (B) Autologous T-cell assay: MoDCs from spondyloarthritis patients were treated as described in (A) and co-cultured with CFSE-labeled CD4 ${ }^{+} \mathrm{T}$ cells from the same patient. CD127- CD25 hi CD45RA ${ }^{-}$Foxp $3^{\text {hi }}$ iTregs were analyzed by flow cytometry. The graph shows the frequency of iTregs as fold change from LPS-treated cells of 4 different spondyloarthritis patients. Data were analyzed by unpaired student's $T$-test.

predominantly direct DC-T cell interaction in combination with the absence of Th-priming cytokines and probably yet unknown DC-secreted factors.

The data from this study are a proof of concept of the potential use of Sa-derived PSM $\alpha 3$ to induce tolerogenic human DCs with the ability to prime $\mathrm{iT}_{\text {regs. }}$ Especially, when using PSM $\alpha 3$ induced $\mathrm{tDCs}$ to prime $\mathrm{iT}_{\text {regs }}$ in allogenic and autologous settings of $\mathrm{CD}^{+}{ }^{+} \mathrm{T}$ cells from spondylitis patients. It is believed that tolerogenic DCs may induce tolerance to the pathologic immune responses in a patient without affecting the immune defense against pathogens or tumors. There are two strategies to restore tolerance in autoimmunity: improve the induction and function of tolerogenic DC or generating tolerogenic DC in vitro for subsequent administration in vivo as cell therapy $(13,56,57)$. Different immune-modulatory agents such as dexamethasone, vitamin D3, TNF or IL-10, but also pathogen-derived products have been used in order to modify the phenotype, cytokine profiles and activity of DCs (58-65). Pre-clinical models of arthritis (65), EAE (66), and type 1 diabetes [T1D; (67)] have demonstrated the efficacy of in vitro induced tolerogenic DCbased cell therapy.

There is a need for the complete understanding of the mechanisms that control tolerance and immunity in the context of the complexity and heterogeneity of autoimmune diseases, in which multiple cell types are affected and various genetic backgrounds are involved.

\section{AUTHOR CONTRIBUTIONS}

SA, JR, and NA contributed to the conception and design of the study. JR and MG performed the experiments and statistical analysis. SA and JR wrote the first draft of the manuscript. SA, JR, NA, MG, and JH wrote sections of the manuscript. All authors read and approved the submitted version of the manuscript.

\section{FUNDING}

This work was financed by the German Research Foundation grant SFB685-TP3 and the European Social Fund of BadenWürttemberg (Margarete von Wrangell Program) to SA.

\section{ACKNOWLEDGMENTS}

We thank Johannes Morschl for technical assistance and Peter Richardson for critical reading of the manuscript. Cell sorting and flow cytometry sample acquisition was done on shared instruments of the Flow Cytometry Core Facility Tübingen. Imaging flow cytometry sample acquisition, and data analysis was done on shared instruments of the Imaging Flow Cytometry Core Facility Tübingen. The Imaging Flow Cytometry Core Facility was supported by a grant from the Ministry of Science, Research and Arts of Baden Württemberg (Az.: SI-BW 01222-91) and the Deutsche Forschungsgemeinschaft DFG (German Research Foundation) (Az.: INST 2388/33-1).

\section{SUPPLEMENTARY MATERIAL}

The Supplementary Material for this article can be found online at: https://www.frontiersin.org/articles/10.3389/fimmu. 2018.02603/full\#supplementary-material 


\section{REFERENCES}

1. Merad M, Sathe P, Helft J, Miller J, Mortha A. The dendritic cell lineage: ontogeny and function of dendritic cells and their subsets in the steady state and the inflamed setting. Annu Rev Immunol. (2013) 31:563-604. doi: 10.1146/annurev-immunol-020711-074950

2. Villadangos JA, Schnorrer P. Intrinsic and cooperative antigen-presenting functions of dendritic-cell subsets in vivo. Nat Rev Immunol. (2007) 7:543-55. doi: $10.1038 /$ nri2103

3. Banchereau J, Steinman RM. Dendritic cells and the control of immunity. Nature (1998) 392:245-52. doi: 10.1038/32588

4. Banchereau J, Briere F, Caux C, Davoust J, Lebecque S, Liu Y-J, et al. Immunobiology of dendritic cells. Annu Rev Immunol. (2000) 18:767-811. doi: 10.1146/annurev.immunol.18.1.767

5. Coquet JM, Rausch L, Borst J. The importance of co-stimulation in the orchestration of $\mathrm{T}$ helper cell differentiation. Immunol Cell Biol. (2015) 93:780-8. doi: 10.1038/icb.2015.45

6. Gordon JR, Ma Y, Churchman L, Gordon SA, Dawicki W. Regulatory dendritic cells for immunotherapy in immunologic diseases. Front Immunol. (2014) 5:7. doi: 10.3389/fimmu.2014.00007

7. Kushwah R, Hu J. Role of dendritic cells in the induction of regulatory T cells. Cell Biosci. (2011) 1:20. doi: 10.1186/2045-3701-1-20

8. Raker VK, Domogalla MP, Steinbrink K. Tolerogenic dendritic cells for regulatory $\mathrm{T}$ cell induction in man. Front Immunol. (2015) 6:569. doi: 10.3389/fimmu.2015.00569

9. Yoo S, Ha S-J. Generation of tolerogenic dendritic cells and their therapeutic applications. Immune Netw. (2016) 16:52-9. doi: 10.4110/in.2016.16.1.52

10. Armbruster NS, Richardson JR, Schreiner J, Klenk J, Günter M, Kretschmer D, et al. PSM peptides of Staphylococcus aureus activate the p38-CREB pathway in dendritic cells, thereby modulating cytokine production and $\mathrm{T}$ cell priming. J Immunol. (2016) 196:1284-92. doi: 10.4049/jimmunol.1502232

11. Ouyang W, Rutz S, Crellin NK, Valdez PA, Hymowitz SG. Regulation and functions of the IL-10 family of cytokines in inflammation and disease. Annu Rev Immunol. (2011) 29:71-109. doi: 10.1146/annurev-immunol-031210-101312

12. Schreiner J, Kretschmer D, Klenk J, Otto M, Bühring H-J, Stevanovic S, et al. Staphylococcus aureus phenol-soluble modulin peptides modulate dendritic cell functions and increase in vitro priming of regulatory T cells. J Immunol. (2013) 190:3417-26. doi: 10.4049/jimmunol.1202563

13. Maldonado RA, Andrian von UH. How tolerogenic dendritic cells induce regulatory $\mathrm{T}$ cells. Adv Immunol. (2010) 108:111-65. doi: 10.1016/B978-0-12-380995-7.00004-5

14. Otto M. Phenol-soluble modulins. Int J Med Microbiol. (2014) 304:164-9. doi: 10.1016/j.ijmm.2013.11.019

15. Wang R, Braughton KR, Kretschmer D, Bach T-HL, Queck SY, Li $\mathrm{M}$, et al. Identification of novel cytolytic peptides as key virulence determinants for community-associated MRSA. Nat Med. (2007) 13:1510-4. doi: $10.1038 / \mathrm{nm} 1656$

16. Peschel A, Otto M. Phenol-soluble modulins and staphylococcal infection. Nat Rev Microbiol. (2013) 11:667-73. doi: 10.1038/nrmicro3110

17. Cheung GYC, Kretschmer D, Duong AC, Yeh AJ, Ho TV, Chen Y, et al. Production of an attenuated phenol-soluble modulin variant unique to the MRSA clonal complex 30 increases severity of bloodstream infection. PLoS Pathog. (2014) 10:e1004298. doi: 10.1371/journal.ppat.1004298.s002

18. Armbruster NS, Richardson JR, Schreiner J, Klenk J, Günter M, Autenrieth SE. Staphylococcus aureus PSM peptides induce tolerogenic dendritic cells upon treatment with ligands of extracellular and intracellular TLRs. Int J Med Microbiol. (2016) 306:666-74. doi: 10.1016/j.ijmm.2016.09.002

19. Autenrieth SE, Soldanova I, Rösemann R, Gunst D, Zahir N, Kracht $\mathrm{M}$, et al. Yersinia enterocolitica YopP inhibits MAP kinase-mediated antigen uptake in dendritic cells. Cell Microbiol. (2007) 9:425-37. doi: 10.1111/j.1462-5822.2006.00800.x

20. Burgdorf S, Kautz A, Böhnert V, Knolle PA, Kurts C. Distinct pathways of antigen uptake and intracellular routing in $\mathrm{CD} 4$ and $\mathrm{CD} 8 \mathrm{~T}$ cell activation. Science (2007) 316:612-6. doi: 10.1126/science.1137971

21. Platt CD, Ma JK, Chalouni C, Ebersold M, Bou-Reslan H, Carano RAD, et al. Mature dendritic cells use endocytic receptors to capture and present antigens. Proc Natl Acad Sci USA. (2010) 107:4287-92. doi: 10.1073/pnas.0910609107
22. West MA, Wallin RPA, Matthews SP, Svensson HG, Zaru R, Ljunggren H-G, et al. Enhanced dendritic cell antigen capture via toll-like receptor-induced actin remodeling. Science (2004) 305:1153-7. doi: 10.1126/science.1099153

23. Pokorny A, Yandek LE, Elegbede AI, Hinderliter A, Almeida PFF. Temperature and composition dependence of the interaction of $\delta$-lysin with ternary mixtures of sphingomyelin/cholesterol/POPC. Biophys J. (2006) 91:2184-97. doi: 10.1529/biophysj.106.085027

24. Li P, Spolski R, Liao W, Leonard WJ. Complex interactions of transcription factors in mediating cytokine biology in T cells. Immunol Rev. (2014) 261:14156. doi: 10.1111/imr.12199

25. Zou W, Restifo NP. TH17 cells in tumour immunity and immunotherapy. Nat Rev Immunol. (2010) 10:248-56. doi: 10.1038/nri2742

26. Santegoets SJAM, Dijkgraaf EM, Battaglia A, Beckhove P, Britten CM, Gallimore A, et al. Monitoring regulatory $\mathrm{T}$ cells in clinical samples: consensus on an essential marker set and gating strategy for regulatory T cell analysis by flow cytometry. Cancer Immunol Immunother. (2015) 64:1271-86. doi: $10.1007 / \mathrm{s} 00262-015-1729-\mathrm{x}$

27. Salazar F, Awuah D, Negm OH, Shakib F, Ghaemmaghami AM. The role of indoleamine 2,3-dioxygenase-aryl hydrocarbon receptor pathway in the TLR4-induced tolerogenic phenotype in human DCs. Sci Rep. (2017) 7:43337. doi: 10.1038/srep43337

28. Ardeshna KM, Pizzey AR, Devereux S, Khwaja A. The PI3 kinase, p38 SAP kinase, and NF-kappaB signal transduction pathways are involved in the survival and maturation of lipopolysaccharide-stimulated human monocytederived dendritic cells. Blood (2000) 96:1039-46.

29. Dalod M, Chelbi R, Malissen B, Lawrence T. Dendritic cell maturation: functional specialization through signaling specificity and transcriptional programming. EMBO J. (2014) 33:1104-16. doi: 10.1002/embj.201488027

30. Kaisho T, Akira S. Dendritic-cell function in toll-like receptorand MyD88- knockout mice. Trends Immunol. (2001) 22:78-83. doi: 10.1016/S1471-4906(00)01811-1

31. Chu M, Zhou M, Jiang C, Chen X, Guo L, Zhang M, et al. Staphylococcus aureus phenol-soluble modulins $\alpha 1-\alpha 3$ act as novel toll-like receptor (TLR) 4 antagonists to inhibit HMGB1/TLR4/NF- $\mathrm{kB}$ signaling pathway. Front Immunol. (2018) 9:862. doi: 10.3389/fimmu.2018.00862

32. Iruretagoyena MI. Inhibition of nuclear factor- B enhances the capacity of immature dendritic cells to induce antigen-specific tolerance in experimental autoimmune encephalomyelitis. J Pharmacol Exp Therapeut. (2006) 318:5967. doi: $10.1124 /$ jpet.106.103259

33. Li $M$, Zhang $X$, Zheng $X$, Lian $D$, Zhang ZX, Ge W, et al. Immune modulation and tolerance induction by RelB-silenced dendritic cells through RNA interference. J Immunol. (2007) 178:5480-7. doi: 10.4049/jimmunol.178.9.5480

34. Martin E, Capini C, Duggan E, Lutzky VP, Stumbles P, Pettit AR, et al. Antigen-specific suppression of established arthritis in mice by dendritic cells deficient in NF-kappaB. Arthritis Rheum. (2007) 56:2255-66. doi: 10.1002/art.22655

35. Thompson AG, O'Sullivan BJ, Beamish H, Thomas R. T cells signaled by NFkappa B- dendritic cells are sensitized not anergic to subsequent activation. $J$ Immunol. (2004) 173:1671-80. doi: 10.4049/jimmunol.173.3.1671

36. Li H, Shi B. Tolerogenic dendritic cells and their applications in transplantation. Cell Mol Immunol. (2015) 12:24-30. doi: 10.1038/cmi.2014.52

37. Lavelle EC, McNeela E, Armstrong ME, Leavy O, Higgins SC, Mills KHG. Cholera toxin promotes the induction of regulatory $\mathrm{T}$ cells specific for bystander antigens by modulating dendritic cell activation. J Immunol. (2003) 171:2384-92. doi: 10.4049/jimmunol.171.5.2384

38. Danese S, Sans M, Scaldaferri F, Sgambato A, Rutella S, Cittadini A, et al. TNF- blockade down-regulates the CD40/CD40L pathway in the mucosal microcirculation: a novel anti-inflammatory mechanism of infliximab in Crohn's disease. J Immunol. (2006) 176:2617-24. doi: 10.4049/jimmunol.176.4.2617

39. Quezada SA, Jarvinen LZ, Lind EF, Noelle RJ. CD40/CD154 interactions at the interface of tolerance and immunity. Annu Rev Immunol. (2004) 22:307-28. doi: 10.1146/annurev.immunol.22.012703.104533

40. Pletinckx K, Döhler A, Pavlovic V, Lutz MB. Role of dendritic cell maturity/costimulation for generation, homeostasis, and suppressive activity of regulatory T cells. Front Immun. (2011) 2:39. doi: 10.3389/fimmu.2011.00039 
41. Spörri R, Reis e Sousa C. Inflammatory mediators are insufficient for full dendritic cell activation and promote expansion of $\mathrm{CD} 4^{+} \mathrm{T}$ cell populations lacking helper function. Nat Immunol. (2005) 6:163-70. doi: 10.1038/ni1162

42. Akbari O, DeKruyff RH, Umetsu DT. Pulmonary dendritic cells producing IL-10 mediate tolerance induced by respiratory exposure to antigen. Nat Immunol. (2001) 2:725-31. doi: 10.1038/90667

43. McGuirk P, McCann C, Mills KHG. Pathogen-specific T regulatory 1 cells induced in the respiratory tract by a bacterial molecule that stimulates interleukin 10 production by dendritic cells: a novel strategy for evasion of protective T helper type 1 responses by Bordetella pertussis. J Exp Med. (2002) 195:221-31. doi: 10.1084/jem.20011288

44. Murai M, Turovskaya O, Kim G, Madan R, Karp CL, Cheroutre H, et al. Interleukin 10 acts on regulatory $\mathrm{T}$ cells to maintain expression of the transcription factor Foxp3 and suppressive function in mice with colitis. Nat Immunol. (2009) 10:1178-84. doi: 10.1038/ni.1791

45. Wakkach A, Fournier N, Brun V, Breittmayer J-P, Cottrez F, Groux H. Characterization of dendritic cells that induce tolerance and $\mathrm{T}$ regulatory 1 cell differentiation in vivo. Immunity (2003) 18:605-17. doi: 10.1016/S1074-7613(03)00113-4

46. Bonifazi P, Zelante T, D’Angelo C, De Luca A, Moretti S, Bozza S, et al. Balancing inflammation and tolerance in vivo through dendritic cells by the commensal Candida albicans. Mucosal Immunol. (2009) 2:362-74. doi: $10.1038 / \mathrm{mi} .2009 .17$

47. Falcón C, Carranza F, Martínez FF, Knubel CP, Masih DT, Motrán CC, et al. Excretory-secretory products (ESP) from Fasciola hepatica induce tolerogenic properties in myeloid dendritic cells. Vet Immunol Immunopathol. (2010) 137:36-46. doi: 10.1016/j.vetimm.2010.04.007

48. Campbell DJ, Koch MA. Phenotypical and functional specialization of $\mathrm{FOXP}^{+}$regulatory T cells. Nat Rev Immunol. (2011) 11:119-30. doi: $10.1038 /$ nri2916

49. Bubnoff Von D, Scheler M, Wilms H, Fimmers R, Bieber T. Identification of IDO-positive and IDO-negative human dendritic cells after activation by various proinflammatory stimuli. J Immunol. (2011) 186:6701-9. doi: 10.4049/jimmunol.1003151

50. Harden JL, Egilmez NK. Indoleamine 2,3-dioxygenase and dendritic cell tolerogenicity. Immunol Invest. (2012) 41:738-64. doi: 10.3109/08820139.2012.676122

51. Munn DH, Mellor AL. Indoleamine 2,3 dioxygenase and metabolic control of immune responses. Trends Immunol. (2013) 34:137-43. doi: 10.1016/j.it.2012.10.001

52. Baban B, Chandler PR, Sharma MD, Pihkala J, Koni PA, Munn DH, et al. IDO activates regulatory $\mathrm{T}$ cells and blocks their conversion into Th17-like $\mathrm{T}$ cells. J Immunol. (2009) 183:2475-83. doi: 10.4049/jimmunol.0900986

53. Chen W, Liang X, Peterson AJ, Munn DH, Blazar BR. The indoleamine 2,3-dioxygenase pathway is essential for human plasmacytoid dendritic cellinduced adaptive T regulatory cell generation. J Immunol. (2008) 181:5396404. doi: 10.4049/jimmunol.181.8.5396

54. Hwu P, Du MX, Lapointe R, Do M, Taylor MW, Young HA. Indoleamine 2,3-dioxygenase production by human dendritic cells results in the inhibition of $\mathrm{T}$ cell proliferation. J Immunol. (2000) 164:3596-9. doi: 10.4049/jimmunol.164.7.3596

55. Salazar F, Hall L, Negm OH, Awuah D, Tighe PJ, Shakib F, et al. The mannose receptor negatively modulates the toll-like receptor 4-aryl hydrocarbon receptor-indoleamine 2,3-dioxygenase axis in dendritic cells affecting $\mathrm{T}$ helper cell polarization. J Allergy Clin Immunol. (2016) 137:1841-51.e2. doi: $10.1016 /$ j.jaci.2015.10.033
56. Amodio G, Gregori S. Dendritic cells a double-edge sword in autoimmune responses. Front Immunol. (2012) 3:233. doi: 10.3389/fimmu.2012. 00233

57. Lutz MB. Therapeutic potential of semi-mature dendritic cells for tolerance induction. Front Immunol. (2012) 3:123. doi: 10.3389/fimmu.2012. 00123

58. Gregori S, Tomasoni D, Pacciani V, Scirpoli M, Battaglia M, Magnani CF, et al. Differentiation of type $1 \mathrm{~T}$ regulatory cells (Tr1) by tolerogenic DC-10 requires the IL-10-dependent ILT4/HLA-G pathway. Blood (2010) 116:93544. doi: 10.1182/blood-2009-07-234872

59. Penna G, Adorini L. 1 Alpha,25-dihydroxyvitamin D3 inhibits differentiation, maturation, activation, and survival of dendritic cells leading to impaired alloreactive T cell activation. I Immunol. (2000) 164:2405-11. doi: 10.4049/jimmunol.164.5.2405

60. Piemonti L, Monti P, Allavena P, Sironi M, Soldini L, Leone BE, et al. Glucocorticoids affect human dendritic cell differentiation and maturation. J Immunol. (1999) 162:6473-81.

61. Sato M, Takayama T, Tanaka H, Konishi J, Suzuki T, Kaiga T, et al. Generation of mature dendritic cells fully capable of $\mathrm{T}$ helper type 1 polarization using OK-432 combined with prostaglandin E(2). Cancer Sci. (2003) 94:1091-8. doi: 10.1111/j.1349-7006.2003.tb01405.x

62. Steinbrink K, Graulich E, Kubsch S, Knop J, Enk AH. CD4 ${ }^{+}$and $\mathrm{CD}^{+}$anergic $\mathrm{T}$ cells induced by interleukin-10-treated human dendritic cells display antigen-specific suppressor activity. Blood (2002) 99:2468-76. doi: 10.1182/blood.V99.7.2468

63. Steinbrink K, Wölfl M, Jonuleit H, Knop J, Enk AH. Induction of tolerance by IL-10-treated dendritic cells. J Immunol. (1997) 159:4772-80.

64. Van Brussel I, Lee WP, Rombouts M, Nuyts AH, Heylen M, De Winter BY, et al. Tolerogenic dendritic cell vaccines to treat autoimmune diseases: can the unattainable dream turn into reality? Autoimmun Rev. (2014) 13:138-50. doi: 10.1016/j.autrev.2013.09.008

65. van Duivenvoorde LM, Han WGH, Bakker AM, Louis-Plence P, Charbonnier L-M, Apparailly F, et al. Immunomodulatory dendritic cells inhibit Th1 responses and arthritis via different mechanisms. J Immunol. (2007) 179:1506-15. doi: 10.4049/jimmunol.179.3.1506

66. Menges $M$, Rößner $S$, Voigtländer C, Schindler $H$, Kukutsch NA, Bogdan C, et al. Repetitive injections of dendritic cells matured with tumor necrosis factor alpha induce antigen-specific protection of mice from autoimmunity. J Exp Med. (2002) 195:15-21. doi: 10.1084/jem.200 11341

67. Feili-Hariri M, Falkner DH, Morel PA. Regulatory Th2 response induced following adoptive transfer of dendritic cells in prediabetic NOD mice. Eur J Immunol. (2002) 32:2021-30. doi: 10.1002/15214141(200207)32:7<2021::AID-IMMU2021>3.0.CO;2-J

Conflict of Interest Statement: The authors declare that the research was conducted in the absence of any commercial or financial relationships that could be construed as a potential conflict of interest.

Copyright (C) 2018 Richardson, Armbruster, Günter, Henes and Autenrieth. This is an open-access article distributed under the terms of the Creative Commons Attribution License (CC BY). The use, distribution or reproduction in other forums is permitted, provided the original author(s) and the copyright owner(s) are credited and that the original publication in this journal is cited, in accordance with accepted academic practice. No use, distribution or reproduction is permitted which does not comply with these terms. 